\title{
The Application of Genetic Algorithms for the Selection of WSE Companies in Warsaw for an Investment Portfolio
}

\author{
Beata Basiura*, Joanna Motyczyńska**
}

\begin{abstract}
Portfolio analysis is a tool in particular, intended for investors. Risk assessment and risk specification make the investor able to diversify properly and offset the portfolio. Broadly speaking, there are multiple tools designed to create an efficient set of portfolios. One of them is Markowitz's model theory, postulating building up a portfolio to determine the basis of equilibrium between expected profit level as well as accepted level of risk assessment. In the context of this paper, the objective is to shed some light on creating investment portfolios based on either Markowitz's portfolio theory or an evolutionary algorithm. The simulation based methods for building up a portfolio of approximately 40-50 companies listed on the primary market of the Warsaw Stock Exchange using the specific selection function are presented. Portfolio profit values have been evaluated in a dynamically shifted time window. The conducted analysis showed shifts in the economy at certain periods of time. The implemented genetic algorithms smoothly handled the optimization with a relatively short processing time of the task result.
\end{abstract}

Keywords: Markowitz model, investment portfolio, genetic algorithm

Submitted: May 18, 2020

Revised: June 30, 2020

(C) 2020 Authors. This is an open access publication, which can be used, distributed and reproduced in any medium according to the Creative Commons CC-BY 4.0 License. License requiring that the original work has been properly cited.

\section{INTRODUCTION}

The Warsaw Stock Exchange (https://www.gpw.pl/) is a financial institution where buyers and sellers exchange certain financial instruments based on a mutually fixed price. The purpose of the investment for the money-depositing clients revolves around profit, whereas issuers stress the importance of raising the funds (Tarczyński, 2001).

* AGH University of Science and Technology; Department of Management, Krakow, Poland, e-mail: bbasiura@zarz.agh.edu.pl

** Independent Scholar, Krakow, Poland 
Making a profit or loss depends on numerous factors. The background knowledge about the functioning of the stock exchange on which investments are planned, insight on the instruments available on the given market and available investment strategies is the basis.

Technological advances and the development of science have led to raising mindfulness in making decisions among investors through investment processes. Better understanding of the regularities involved in trading securities is the foundation of informed investment. Through the use of many fields of science, such as mathematics, statistics and econometrics, one can strive to know the value of securities in the future. The basis for investment decisions made for investors have become methods of forecasting rates and predicting market changes. The development of many fields of science has allowed the creation of a wide range of tools and methods, including prognostic ones, which support the explanation of phenomena occurring on the stock exchange, and thus, conscious investment risk taking. The use of new programming languages offers many opportunities in creating simple applications to support investors in making decisions.

The stock exchange, which is the market for trading stocks, bonds and derivatives, gives the opportunity to earn fortunes but also incur great losses (Kachniewski, 2008). Although the scientific development in the field of forecasting economic markets has provided investors with many indicators and methods supportive for making investment decisions, it still remains unclear that forecasts made using these methods will ensure investment returns. Investing in listed instruments is intrinsically linked to relatively high risks. Important decisions are made especially while selecting instruments for the investment portfolio. The use of a specific method for selecting companies regarding a portfolio or investment strategy allows this risk to be significantly reduced (Tarczyński \& Euniewska, 2004)

There are multiple methods for creating investment portfolios on the capital market. In the relevant literature (see Czekała, 1997; Haugen 2000; Jajuga \& Jajuga, 2006; Graham, 2006; Krzywda, 2010, Ostrowska, 2011; Tarczyński, 2014; Tarczyński \& Euniewska, 2004) three basic analyses are worth distinguishing: technical analysis, fundamental analysis and portfolio analysis. The basis for technical analysis are specific techniques that are intended for forecasting future courses based on historical data. The key element of technical analysis is the trend, thanks to which it is possible to determine the turning points on the market, which in turn constitute an opportunity for the investor. The fundamental analysis is, however, an analysis of the economic condition of the selected company. The fundamental analysis of its securities assessment takes into account the general situation of the company, its financial analysis and valuation, the situation of the industry and the entire macro environment (Krzywda, 2010; Tarczyński \& Łuniewska, 2004). Portfolio analysis, on the other hand, is a specific investment tool that is used to select and juxtapose relevant shares to reduce the investment risk.

Market models introduced in the portfolio analysis assume the predictability of investor behavior and changes in quotations using mathematical models. This allows one to maximize future income arising from the increase of share prices and the rights conferred by them. However, practical experience has shown that forecasting changes 
in the price of a single share gives very uncertain results (e.g. Markowitz, 1959; Fabozzi et al., 2002; Tarczyński \& Euniewska, 2004). This means that the predictable modeling part of the behavior of one asset is very insignificant. Considering increasing number of shares in the simultaneous analysis and the result of increasing forecasts, which impact on an unfavorable situation for the investor, the reduction of the investment risk is very significant. However, it should be noted that the increase in forecast accuracy depends on the appropriate combination of various values.

According to the model proposed by Markowitz (Markowitz, 1959), each individual investor is characterized by the level of an estimated profit and the risk approved for a given profit. The rate of return determines the long-term trend for behavior of the shares, and the risk allows the assessment of fluctuations around the value determining the trend. The model assumptions indicate the principal regarding taking a minimal risk by investors at a given rate of return, and at the same time with a set risk level for selecting the portfolio with the highest profitability (Tarczyński \& Luniewska, 2004).

Markowitz highlighted that each pair of shares has a correlation coefficient that determines the relationship between the behavior of either asset. A high correlation indicates a similarity in reaction to the action to the same information. A low one indicates a lack of connections, and negative indicates a negative response to any situation. Low or negative correlation should (ideally speaking) characterize the shares of companies belonging to various industries. The portfolio should involve selecting companies with the highest rate of return, the lowest risk and the lowest correlation, which significantly reduces the portfolio risk (Markowitz, 1959; Tarczyński \& Łuniewska, 2004).

The selection method for portfolios proposed by Markowitz and later developed by others, e.g. by Sharpe (Sharp, 1992), has several apparent flaws despite its theoretical attractiveness (Tarczyński, 1996; Tarczyński, 2002; Tarczyński \& Łuniewska, 2004; Ostrowska, 2011). The application of the Markowitz method involves estimating the future rates of return and standard deviations based on data from the past, even though it remains uncertain that historical data will prove to be a good estimation of the future. Furthermore, it is believed that the Markowitz method shows certain vulnerability to even small changes in the period from which the historical data for the conducted analysis comes from.

The primary objective of this paper is to give an insightful look into creating investment portfolios based on Markowitz's portfolio theory and an evolutionary algorithm.

In the literature, apart from genetic algorithms, one can also find other ways to optimize portfolio choices. For example, a multi-purpose portfolio model with an expected rate of return as a measure of performance and the expected worst rate of return as a risk guarantor was presented by B. Sawik (Sawik, 2012). At that time, a three-lensed mixed integer program was formulated and which allowed a compromise to be reached between the conditional VaR (estimated by $\mathrm{VaR}$ and $\mathrm{CVaR}$ ) and the expected rate of return of the portfolio. The two objective linear and integer problem was previously considered by the same author (Sawik, 2009; Sawik, 2010). Jiao and others (Jiao et al., 2007) presented the use of genetic algorithms to select the optimal portfolio of a products set and assigning levels to the target market offer. The condition 
function used here is established on the basis of a surplus shared measure, using both customer needs and engineering problems. Since product portfolio planning is one of the most important decisions to offer "right" products to the target market, genetic algorithms have also been used in this context (Dorostkar-Ahmadi \& Shafiei Nikabadi, 2018). Orito and Yamazaki (Orito \& Yamazaki, 2001) used GA to select a portfolio of index funds in order to minimize risk in the portfolio. A review of the Modern Portfolio Theory literature and the investment selection process was presented by Talebi and the others (Telebi et al., 2010). In order to solve the problem of portfolio selection, a genetic algorithm and particle swarm optimization (PSO) were used, with a view to minimizing risk and maximizing return of investment. Four different portfolios of the top 50 Tehran Stock Exchange companies were considered. The authors demonstrated that the annual genetic portfolio has the best performance compared to its counterparts.

In this work, the created portfolios by genetic optimization will include companies listed in the primary market of the Warsaw Stock Exchange. The publication highlights selected monthly data from January 1, 2015 to March 15, 2020 from stooq.pl. All data refer to 383 companies, although, due to missing information, only 344 items have been included into the analysis. Portfolios with an average of 60 shares were built from these listings. In addition, the quotation periods were divided into one and a half year time windows shifted every six months. The use of time windows allows one to modify a portfolio over time. Within the given ranges of quotations, eight such time windows were identified. For each of them, optimal portfolios have been determined as defined in Markowitz theory. They were built using the R-project application (R Core Team 2019, RStudio Team 2019), based on the evolutionary algorithm.

\section{INVESTMENT PORTFOLIO}

\subsection{Rate of return}

One of the most commonly applied measures of the profitability for investments in securities is the rate of return (see e.g. Jajuga 2006, Jasiński 2008, Fabozzi et al. 2002, Morajda 1999, Tarczyński 1996, Tarczyński \& Euniewska 2004) that can be written as equation (1).

$$
R_{t}=\frac{P_{t}-P_{t-1}+D_{t}}{P_{t-1}}
$$

where:

$R_{t}$ - the rate of return in the period $t$,

$P_{t}$ - price of the security in the period $t$,

$P_{t-1}-$ price of the security in the period $t-1$,

$D_{t}$ - dividend paid in the period $t$.

For the period $t$ for instance, day, week, month, quarter or year can be taken into account. Based on this information, it is possible to determine the expected value of profit or loss, which results from price variance for $t-1$ and $t$ prices, including dividend payments. When selecting shares for the portfolio, the highest rate of return should 
be preferably applied. Unluckily, such a choice is supported by historic data. Broadly speaking, this historic data is a ground rule applied for estimating the likelihood for obtaining a specific rate of return, and then assessing is the expected rate of return with equation (1).

$$
E(R)=\frac{1}{N} \sum_{i=1}^{N} R_{i}
$$

where:

$E(R)$ - expected rate of return on investment (mathematical hope),

$R_{i}-i$-th empirical rate of return determined with equation (1),

$N$ - number of rates of return considered.

\subsection{Risk measurement}

Any investment may involve a certain level of risk. In particular, investments in securities may be also subject to risk. Taking a look at equity investments in general, risks can result from multiple factors. There are external factors, mainly regarding the environment of the companies and the market situation, as well as internal factors, related primarily to decisions taken by the companies and their management boards. However, risk remains a very complex and ambiguous concept. By limiting the notion of risk to investment on the WSE and portfolio analysis, the risk measures referred to standard deviation, variance and semivariance of the return rate are considered classical concepts. (see e.g. Jajuga \& Jajuga 2006, Jasiński 2008, Morajda 1999, Ostrowska 2011, Tarczyński 2001, 2002 , Tarczyński \& Łuniewska 2004). The expected rate of return acts as a long-term forecast of stock behavior, while the risk is defined as the level of fluctuations around this expected value. The variance of the rate of return, determined in historical quotations, is calculated by the equation (2).

$$
V=\frac{1}{N-1} \sum_{i=1}^{N}\left(R_{i}-E(R)\right)^{2}
$$

where:

$V$ - the variance of return,

$R_{i}-i$-th empirical rate of return determined according to formula (1),

$E(R)$ - expected rate of return on investment,

$N$ - considered number of rates of return.

Noticeably, the higher the rate of return, the higher the investment risk in the investigated share is. Similarly, the bottom line is related to standard deviation, which is determined by equation (4).

$$
S=\sqrt{V}=\sqrt{\frac{1}{N-1} \sum_{i=1}^{N}\left(R_{i}-E(R)\right)^{2}}
$$


It should be highlighted that the standard deviation is the average deviation of the rate of return on shares from the estimated value of the rate of return on this asset. In classic risk models, defined as the level of fluctuations around estimated value, at the same time positive deviations are also taken into account, i.e. those for which a higher rate of return is realized, and negative deviations in which the realized rate of return is lower. Naturally, a higher rate of return does not pose a threat for investors. Although, negative deviation from estimated rate of return can be distinguished as a particularly high risk circumstance. Risk measure including only undesired, negative deviations from estimated rate of return is semivariance of securities with equation (5).

$$
S V=\frac{1}{N-1} \sum_{i=1}^{N}\left(d_{i}\right)^{2}
$$

where:

$S V$ - semi-variance of rates of return

$d_{i}=\left\{\begin{array}{lll}0 & \text { if } & R_{i}-E(R) \geqslant 0 \\ R_{i}-E(R) & \text { if } & R_{i}-E(R)<0\end{array}\right.$

$R_{i}-i$-th empirical rate of return determined by equation (1),

$E(R)$ - estimated rate of return from investment,

$N$ - number of considered rates of return.

Analogically, as mentioned above, semi-deviation is defined as $s V=\sqrt{S V}$. Semideviation can be generalized for any deviations below certain threshold (substitute for zero), below which the investment is too risky for the investor.

\subsection{Constructing a stock portfolio}

An investment portfolio involves a set of investor assets intended for investing capital for money growth. In particular, the portfolio of shares is a carefully selected set of companies listed on the stock exchange (Tarczyński \& Łuniewska 2004).

Portfolio theory is a framework which allows investors to build up co-called effective portfolios. This also translates into the belief that these models are optimal in terms of profit maximization and simultaneous minimization of risk. The postulates of this theory were published in 1952 and 1959, the later Nobel Prize winner in economics, Harry Max Markowitz (Markowitz 1952, Markowitz 1959, Fabozzi et al. 2002). The key concepts of this theory are coefficients such as, rate of return and risk understood as standard deviation of rates of return, and correlation coefficients of securities. What gets to the heart of Markowitz's theory is that the portfolio should involve companies with the highest rate of return, the lowest risk and low correlation between them (Fabozzi et al. 2002).

The estimated rate of return in the portfolio can be determined as the overall number of the products with the rates of return and the shares of the respective $k$ 's portfolio values with an equation (6).

$$
E\left(R_{p}\right)=\sum_{k=1}^{n} x_{k} \cdot R_{k}
$$


where:

$E\left(R_{p}\right)$ - expected rate of return of the portfolio,

$R_{k}-k$-th estimated rate of return of the $k$-th share determined with an equation $(2)$,

$x_{k}$ - share of stocks in portfolio,

$n$ - number of stocks considered.

The total sum of the parts $x_{k}$ in portfolio shares equals one, and at the same time the contribution of each asset is greater than or equal to zero (see equation 7 ).

$$
\sum_{k=1}^{n} x_{k}=1, x_{k} \geqslant 0
$$

Although, the risk for portfolio is defined by an Equation (8).

$$
V_{p}=\sum_{k=1}^{n} x_{k}^{2} s_{k}^{2}+2 \sum_{k=1}^{n-1} \sum_{j=k+1}^{n} x_{k} x_{j} \operatorname{cov}_{k j}
$$

where:

$V_{p}$ - variances of the whole portfolio,

$x_{k}$ - part of $k$ share in the portfolio,

$s_{k}^{2}-k$-value variance,

$\operatorname{cov}_{k j}$ - covariance between $k$ and $j$ share,

$n$ - number of stocks considered.

Taking into account the risk as the part of the examined rate of return which is allocated below the expected level, the portfolio risk can be determined with the following equation (9)

$$
s V_{p}=\sum_{k=1}^{n} x_{k}^{2} d_{k}^{2}+2 \sum_{k=1}^{n-1} \sum_{j=k+1}^{n} x_{k} x_{j} d_{k} d_{j}
$$

where;

$s V_{p}$ - semi-variance of the entire portfolio,

$x_{k}$ - part of $k$ share in the portfolio,

$d_{k}=\left\{\begin{array}{lll}0 & \text { if } & R_{i}-E\left(R_{k}\right) \geqslant 0 \\ R_{i k}-E\left(R_{k}\right) & \text { if } & R_{i}-E\left(R_{k}\right)<0\end{array}\right.$

$d_{j}$ - similarly as for $d_{k}$,

$n$ - number of stocks considered.

\subsection{The Markowitz model in selecting companies for the stock portfolio}

In modern portfolio theory (MPT), assumes that risk is measured as standard deviation and variance in the probability distribution of future profits (Fabozzi et al. 2002). Although, Markowitz's basic portfolio theory is based on following assumptions:

1) Investors should employ a rational approach conducive for profit maximization increasing their utility with a given level of income or money; 
2) Investors are allowed to have free access to fair, complete and correct information regarding returns and estimated risk; (market is effective in strong form; according to Fama 1970);

3) Markets are efficient and absorb the information relatively fast;

4) Investors are risk averse and therefore take some actions to minimize risk while maximizing the return on investment;

5) Decision making process for investors is based on expected returns and variances or the standard deviation of these returns from the mean;

6) Investors prefer higher than lower returns for a fixed risk level;

Not to mention that you should assume that investors have access to a risk-free rate of return $\left(r_{f}\right)$, i.e. they can borrow and deposit funds, and purchase and sell securities at fixed prices, but their decisions do not have potential to affect share prices themselves. Transaction costs and taxes are also not included and the considered assets are fully divisible respectively.

As mentioned above, estimated rate of return from a portfolio can be determined as the sum of the products of the return rates and the parts of the $k$ 's portfolio shares (see equation 6).

The diversification of shares in the Markowitz model assumes minimizing portfolio variance (see equation 8) and semi-variance (equation 9). Broadly speaking, the Markowitz portfolio diversification theory places emphasis on the standard deviation of this portfolio. Its objective is to reduce the standard deviation value to zero as far as possible. Covariance is also taken into account to obtain the largest possible negative interaction effect between the securities in the portfolio and a negative correlation coefficient, so that the overall risk of the portfolio as a whole is next to zero or very low.

The objective of the model postulated by Markowitz is to achieve the highest possible rate of return on the portfolio while reducing the risk to the lowest possible level. Assessing the risk level in the search for an optimal investment portfolio depends on determining the investor's willingness to take a risk. To obtain such a result, the objective function is formalized with equation (10).

$$
f=-A \cdot E\left(R_{p}\right)+V_{p} \quad \text { dla } \quad 0 \leqslant A \leqslant \infty
$$

where:

$A-$ is an indicator of risk aversion level,

$E\left(R_{p}\right)$ - expected rate of return on the investment portfolio,

$V_{p}$ - expected portfolio risk.

Such a model allows you to extract sets of portfolios with a minimum risk level at a given rate of return and those that obtain a maximum rate of return, assuming a certain level of risk.

\section{THE APPLICATION OF GENETIC ALGORITHM IN THE SELECTION OF COMPANIES FOR THE PORTFOLIO}

The search for an effective portfolio in terms of minimizing risk while maximizing the estimated profit is an optimization issue with two objectives involved. At the same 
time, minimum risk and maximum return on investment are sought. It is assumed that the total sum of weights assigned to each company is 1 and all weights are non-negative.

In such circumstances, evolution algorithms can be applied respectively. They successfully allow addressing optimization problems and finding a potential solution. These algorithms use ground mechanisms occurring in nature such as, selection, reproduction and mutation inspired by the biological evolution process.

The genetic algorithm are comprised of the following components:

- genetic representation of potential task solutions;

- ways of generating the initial population;

- a form of adaptation function that allows species to be selected according to their suitability to the environment,

- ways of selecting the next generation using the adaptation function,

- ways of hybridizing species and their mutations

\subsection{Objective function}

Incorporating these two objectives into one optimization goal can be implemented in various ways. One of them is searching the maximum of the quotient (Eqs. (11) and (12)) of the rate of return and portfolio variance.

$$
f\left(x_{1}, x_{2}, \ldots, x_{N}\right)=\frac{E\left(R_{p}\right)}{V_{p}} \rightarrow \max
$$

Semi-variance can obtained respectively by applying this formula:

$$
f\left(x_{1}, x_{2}, \ldots, x_{N}\right)=\frac{E\left(R_{p}\right)}{s V_{p}} \rightarrow \max
$$

For the research purposes, portfolio selection according to the expressions given in (11) and (12) has been determined as the adaptation function. It was assumed that a better species is the one for which the value of the function (11) or (12) of the target is higher. The proposed formula was introduced in (Motyczyńska 2019).

\subsection{Initial population}

The most essential in genetic algorithm composition is a population composed of chromosomes. Chromosome is a set of genes characterized by certain length (Goldberg 1989, Goldberg \& Sastry 2001, Gwiazda 1998, Michalewicz 2003, Figielska 2006). For the purposes of this study, it was assumed that the chromosome is a set of 344 (because so many items were distinguished on the primary market of the Warsaw Stock Exchange) ones and zeros. Broadly speaking, zero means that the given item is excluded from the portfolio, while one means that it was added to the portfolio by the investor.

Despite numerous studies (Tarczyński \& Łuniewska 2004), it is not yet clear how many shares on a given market should be purchased to obtain a sufficiently diversified 
portfolio in terms of risk measured by variance or semi-variance. For the purposes of the study, portfolios composed of a different number of shares were built (the number of shares drawn could be different in each portfolio). The probability of drawing a company for the portfolio was set at 0.11 , which allowed to construct portfolios with approximately 40 shares drawn from a set of 344 companies.

Each chromosome should be assigned to weights that determine the share of stocks in the portfolio. Three types of randomized allocation for portfolio shares were selected for the purposes of the simulations:

1) Each company from a given chromosome was assigned to a weight from a uniform distribution within the range $[0,1]$. To make the sum of the weights of each portfolio equal 1 , the drawn values were divided by the total sum of all portfolio weights.

2) Each company from a given chromosome has a positive weight drawn with a probability equal to the normal distribution $N(0,1)$. As mentioned before, the assigned weights are normalized by dividing by the sum of all weights. In this way, weights with values closer to zero are more likely than values next to 1 .

3) Each company from a given chromosome is assigned to a positive weight with a probability equal to the inverse of the logarithm for its value. Thus, the probability of drawing relatively large scales is due to be reduced. In this regard, normalization is two-stage. First, all values are divided by the logarithm of 0.01 . Then, in each chromosome, the weights are divided by the sum of all weights.

In the initial population scenario, 2000 spices (portfolios) were drawn. When mixing the three sampling methods, the initial population includes 2,000 portfolios drawn in three ways: 700 from the first generation method and 650 from the second and third. All portfolios in the initial population were organized by the stated objective function (eq. 11 or 12).

\subsection{Crossover and mutation operators}

Genetic algorithms involve defining two basic operators: crossover and mutations. Crossover takes two individuals and produces two new individuals while mutation alters one individual to produce a single new solution. Crossover operators allow generating the next generation of given species. Mutation operator is considered safety buffers not to fall into the local minimums of the objective function.

In relevant literature, there are several ways distinguished for selecting parents for the crossover operator. (Figielska 2006, Goldberg 1989, Goldberg \& Sastry 2001, Gwiazda 1998, Janikow \& Michalewicz, Michalewicz 2003). Two basics are roulette and tournament. Roulette involves determining the cumulative distribution value estimated for each individuals on the basis of the adaptation function. The likelihood of being a parent is higher provided that the part of the value of the adaptation function for a given species in the total sum value of this function for all individuals is higher. In the tournament, however, in each parent selection two units are drawn and the one with better value of the adaptation function is due to be selected. In such a specific parent selection, the species who is better adapted is more likely to be a parent. In the 
The number of possible exchanges of zeros for ones is 60 , while ones for zeros are 58 . We select only 35 chromosomes to change randomly from the available elements (with fixed swap_count $=35$ ). The random elements to be exchanged with one to zero in the first portfolio are chromosomes with numbers: $16,52,63,70,72,83,86,124,136$, $141,143,147,154,155,162,165,173,178,181,182,186,192,201,212,216,228,254$, $265,287,297,301,306,319,340$. The same chromosomes in the second portfolio have zero-to-one values. In the shown portfolios (see Fig. 1 and 2)), each one corresponds to a specific share from the 344 listings available. The indicated chromosome values in both portfolios are put in bold and highlighted in color.

Correspondingly, reverse exchanges have been programmed. Chromosomes numbers $4,8,11,31,32,34,42,57,68,78,87,92,93,97,119,121,158,213,226,229,232$ $241,244,250,253,263,274,277,286,305,314,316,322,330,342$ were drawn here for substitution. Simultaneously with the change in the allocation of companies, the corresponding exchange of the weights given to individual actions occur respectively. Finally, the weights are normalized by being divided by the total sum of the weights in each portfolio.

The second way of crossover is genetic exchange of a chromosome fragment between two parents. The exchange of chromosomes corresponds to the exchange of weight values. For controlling the amount of shares in the portfolio, only the selected number of chromosomes is exchanged. At the beginning, a fragment of the genotype is drawn, which is subject to exchange (in the shown portfolio it is put in bold). Then an equal number of zero-to-one exchanges was determined in such chromosomes, where the second parent changed the one to zero. Correspondingly, in the second parent zeros were converted to ones where the first parent was changed to ones.

Examples of chromosomes for change in a randomly selected individual (see below) are put in bold. In this particular case Portfolio 1 (Fig 3), the components which are to be replaced are chromosomes with numbers 173, 178, 181, 182, 183, 186, 188, 192, 201, 208, 214, 216, 217, 221, 228, 234, 254, 258, 265, 267, 278, 287, 290, 295, 297,300 (marked in red color in Portfolio 1 - Fig. 3). As you can see, these are not all possible exchanges.

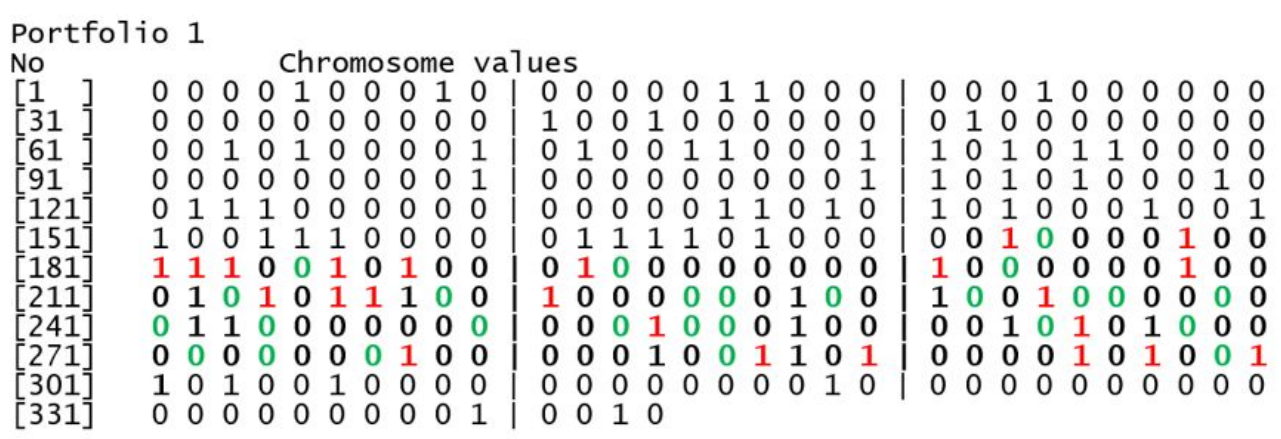

Fig. 3. Portfolio 1 
Reverse exchanges (marked in green in Portfolio 2 - Fig. 4) were correspondingly carried out for chromosomes numbers 174, 185, 193, 203, 213, 219, 225, 226, 229, 232, 235, 236, 239, 241, 244, 250, 253 , 255, 256, 264, 268, 272, 274 277, 286, 299.

The weightings of the shares included in the portfolio have been changed respectively. Added to this mutation operators have also been laid-out so that in a relatively small percentage (percentage of about 5\%) they can change the number of items included in the portfolio. In the whole population, the mutation itself is very rare (the probability of mutation was taken as $\mathrm{p} \_$mute $=0.1$ ).

An example mutation for one of the generated portfolios can be as follows:

1) First, draw the chromosome numbers for a change; this draw is carried out with excess to select from it few chromosomes that change from zero to one and those that change inversely from ones to zero.

2) Subsequently, an equal number of zero to one exchanges and one to zero conversion is determined so that the number of shares in the portfolio can not change.

3) Secondly, a few shares are added to the portfolio if the number of changes was very small or several companies are removed when the number of changes was too large.

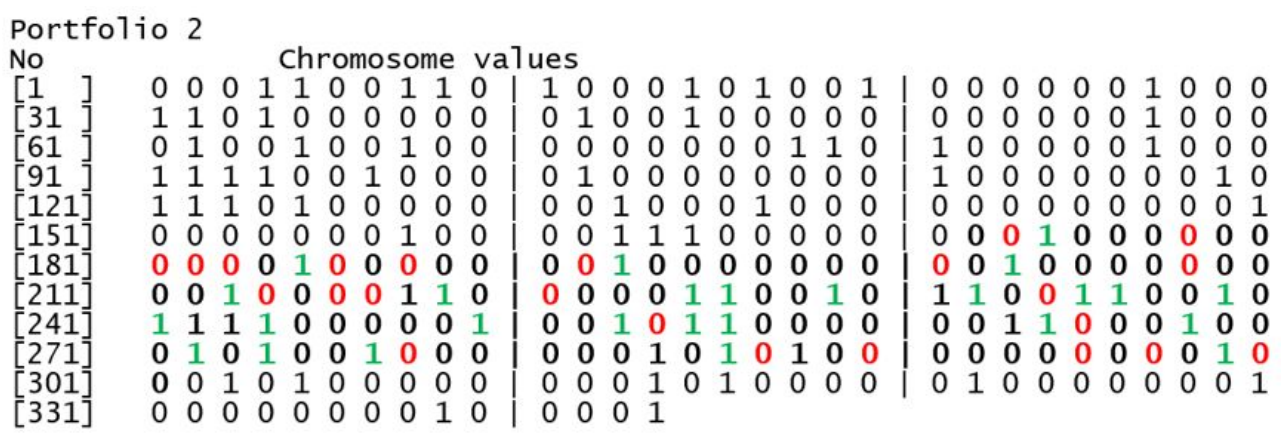

Fig. 4. Portfolio 2

For example, chromosomes of numbers: 4, 18, 19, 27, 31, 35, 41, 49, 63, 73, 74, $78,79,81,90,95,108,122,132,134,135,143,148,153,156,181,183,201,207,208$, $213,216,219,222,228,232,234,235,250,254,258,260,264,265,273$, 283, 284, 291, 311,318 were initially drawn for the portfolio below (put in bold). In this data, there are only 6 ones that can be converted to zeros ( 6 elements out of $344 !)$. The other way you can exchange 45 zeros for ones. In this regard, the number of shares in the portfolio would increase by 41 shares. This is way too much. Therefore, 6 items out of these 45 were drawn to add only 6 removed companies. So we consistently change the selected 6 ones to zeros (marked with a dark background) and the selected 6 zeros into ones (also marked with a dark background). Chromosomes value of zero should be correspondingly inserted for 6 selected companies that are excluded from the portfolio and select very small parts/sections for 6 items that will be included in the portfolio for this operation (Fig. 5). 


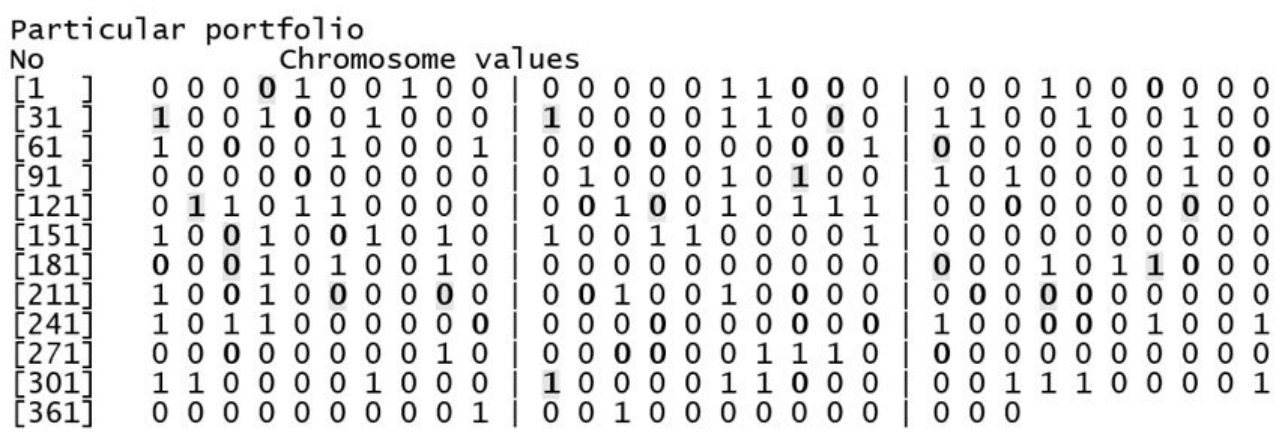

Fig. 5. Particular portfolio

To recap, let's verify the number of exchanges. If the return number is less than $1 \%$ of the assets of the whole portfolio, we add a few shares. If the number of changes is higher than $10 \%$ of the portfolio's assets, several shares are removed from the portfolio.

\section{EMPIRICAL EXAMPLE}

383 monthly quotations of listed companies were extracted from the stock exchange for the period from January 1, 2015 to March 15, 2020. The extracted data was further preprocessed to reduce missing values. Listings with missing values exceeding $10 \%$ of all quotations were excluded from selected data. As a result, this process reduced the number of companies all the way up to 344 . Other missing data was filled in compliance with the rule of linear additions for a time series.

The quotation periods are divided into one and a half year time windows changed every six months. In the given period you can distinguish eight such time windows. On the basis of theory demonstrated by Markowitz, in each of them optimal portfolios can be determined. The average rates of return for each share, their variance and semi-variance, were calculated in each window respectively. Based on this, standard deviations and semi-deviations can be calculated. Either in the randomized experiment or in the genetic algorithm, the most well-adapted portfolio was selected in each window. Modifications and changes of stock portfolio composition along with the received portfolio parameters are collected in the next sections.

\subsection{Randomly stock portfolio composition}

By applying the methods of data generation demonstrated in chapter 3.2, different populations were generated consisting of every 2,000 portfolios (including a mixed population the total 8,000 portfolios are constructed), and thus the optimal portfolio was determined based on the generated data in relation to the objective function mentioned in chapter 3.1. Because the input data was divided into designated time windows, in each such period of time an optimal portfolio was compiled in accordance with Markowitz Portfolio Theory. The collected results of the conducted experiments are included in tables 1-4 and showed in figures 6-7. 
Table 1 summarizes the results of optimal portfolios obtained on the basis of the draw. In this table, the most profitable portfolios can be seen for the third and fourth periods, i.e. for the years 2016/2017. Portfolios built on the basis of data from the time intervals $1 / 31 / 2016-6 / 30 / 2017$ and $7 / 31 / 2016-12 / 31 / 2017$ (put in bold in table 1) achieved the highest quotient of rate of return and variance. These are portfolios with a relatively largest number of shares. The portfolio with the highest quotient of the rate of return and variance, assembled from shares of 48 companies, achieved the result of the objective function 31.61. Hence, one can conclude that the stock market will rise over the years $2016 / 2017$. The sixth and seventh period are the worst ones out of all periods shown (marked in table 1 with a darker background). In particular the time interval $7 / 31 / 2017-12 / 31 / 2018$ stands out significantly. 32 randomized shares obtained a rate of return of 0.00855 . The lowest result regarding the quotient of the rate of return and variance is received for the entire range of time $(1 / 31 / 2015-3 / 31 / 2020)$. The portfolio, including 27 companies, achieves a rate of return of 0.01274 .

Table 1. Optimal portfolios determined by variance (equation 11) based on a draw in individual time windows and for the entire data time. The population number is 8,000 randomly drawn portfolios

\begin{tabular}{|c|c|c|c|c|c|}
\hline \multirow{2}{*}{$\begin{array}{l}\text { Number of } \\
\text { shares } \\
\text { in portfolio }\end{array}$} & \multirow[b]{2}{*}{$\begin{array}{c}\text { Time } \\
\text { window }\end{array}$} & \multirow[b]{2}{*}{ Period } & \multicolumn{3}{|c|}{ Optimal portfolio parameters } \\
\hline & & & Rate of return & $\begin{array}{l}\text { Standard } \\
\text { deviation }\end{array}$ & $\begin{array}{l}\text { Quotient of rate of } \\
\text { return and variance }\end{array}$ \\
\hline $\mathrm{n}=45$ & $31^{\text {st }}$ Jan $2015-30^{\text {th }}$ Jun 2016 & $(1)$ & 0.01725 & 0.02898 & 20.53976 \\
\hline $\mathrm{n}=45$ & $31^{\text {st }}$ Jul $2015-31^{\text {st }}$ Dec 2016 & $(2)$ & 0.01725 & 0.02898 & 20.53976 \\
\hline $\mathrm{n}=48$ & $31^{\text {st }}$ Jan $2016-30^{\text {th }}$ Jun 2017 & (3) & 0.02480 & 0.02801 & 31.61086 \\
\hline $\mathbf{n}=\mathbf{5 0}$ & $31^{\text {st }}$ Jul $2016-31^{\text {st }}$ Dec 2017 & (4) & 0.01309 & 0.02108 & 29.46797 \\
\hline $\mathrm{n}=33$ & $31^{\text {st }}$ Jan $2017-30^{\text {th }}$ Jun 2018 & $(5)$ & 0.01780 & 0.03246 & 16.88705 \\
\hline $\mathrm{n}=32$ & $31^{\text {st }}$ Jul $2017-31^{\text {st }}$ Dec 2018 & (6) & 0.00855 & 0.03169 & 8.51597 \\
\hline $\mathrm{n}=45$ & $31^{\text {st }}$ Jan $2018-30^{\text {th }}$ Jun 2019 & $(7)$ & 0.01471 & 0.03959 & 9.38376 \\
\hline $\mathrm{n}=26$ & $31^{\text {st }}$ Jul $2018-31^{\text {st }}$ Dec 2019 & $(8)$ & 0.01456 & 0.03118 & 14.97893 \\
\hline $\mathrm{n}=27$ & $31^{\text {st }}$ Jan $2015-31^{\text {st }}$ Mar 2020 & Entire period & 0.01274 & 0.04802 & 5.52492 \\
\hline
\end{tabular}

Source: own study based on simulations.

Table 2 offers insight into the stock portfolio compositions in optimal portfolios received from randomly selected companies applying the quotient of the ratio of return and the variance in particular time windows and for the entire range of data. The obtained optimal portfolios are characterized by a certain degree of diversification. Portfolio diversification involves differentiating the set of portfolios to reduce the specific risk of individual assets and, consequently, the entire portfolio.

An example of the application of diversification is the best obtained optimal portfolio selected, which includes assets from various market sectors. Among the companies with their shares in the optimal portfolio, companies ranked among almost each of the eleven industry indexes can be distinguished. The companies related to WIG-banking and WIG-construction indexes show the superiority over the others. 
Table 2. Stock optimal portfolio compositions assembled from the random population in a given period using objective function with variance (Eq. (11))

\begin{tabular}{|c|c|c|}
\hline $\begin{array}{l}\text { Number of } \\
\text { shares } \\
\text { in portfolio }\end{array}$ & $\begin{array}{c}\text { Time } \\
\text { window }\end{array}$ & Stock portfolio composition \\
\hline $\mathrm{n}=45$ & (1) & $\begin{array}{l}\text { "AGO" "AWM" "ALR" "AMB" "AMC" "ATC" "ASM" "ABS" "AST" } \\
\text { "ATP" "BST" "BIK" "BIO" "BOS" "EFK" "ELT" "EMT" "ENA" } \\
\text { "GRN" "IDA" "IFI" "KER" "KTY" "KOM" "LSI" "MOJ" "MZN" } \\
\text { "MZA" "OEX" "OPM" "OBL" "OVO" "PCR" "PPS" "PKN" "PKO" } \\
\text { "PKP" "RMK" "SFG" "SKH" "SPH" "TMR" "URS" "WWL" "ZRE" }\end{array}$ \\
\hline $\mathrm{n}=45$ & $(2)$ & $\begin{array}{l}\text { "AGO" "AWM" "ALR" "AMB" "AMC" "ATC" "ASM" "ABS" "AST" } \\
\text { "ATP" "BST" "BIK" "BIO" "BOS" "EFK" "ELT" "EMT" "ENA" } \\
\text { "GRN" "IDA" "IFI" "KER" "KTY" "KOM" "LSI" "MOJ" "MZN" } \\
\text { "MZA" "OEX" "OPM" "OBL" "OVO" "PCR" "PPS" "PKN" "PKO" } \\
\text { "PKP" "RMK" "SFG" "SKH" "SPH" "TMR" "URS" "WWL" "ZRE" }\end{array}$ \\
\hline $\mathrm{n}=48$ & $(3)$ & $\begin{array}{l}\text { "ABE" "ALR" "AMB" "APT" "ART" "ASE" "ATS" "ATG" "BDZ" } \\
\text { "BFT" "BML" "BOS" "CIE" "COG" "DEL" "DNP" "ECH" "ELZ" } \\
\text { "ENT" "GRN" "GTC" "BHW" "IDM" "INF" "IPE" "KGN" "KPD" } \\
\text { "KRK" "MGT" "MIL" "NTU" "NVA" "PBX" "PXM" "SNW" "SWG" } \\
\text { "SFG" "SKH" "SPH" "STP" "TRR" "TIM" "TOA" "TRK" "WXF" } \\
\text { "WLT" "WIK" "WTN" }\end{array}$ \\
\hline $\mathrm{n}=50$ & $(4)$ & $\begin{array}{l}\text { "ALR" "ARC" "ASM" "ABS" "ATP" "BAH" "BDZ" "BNP" "BBT" } \\
\text { "DBC" "DEK" "DNP" "DPL" "EDI" "EEX" "ELT" "IDA" "IMP" } \\
\text { "INC" "INK" "IRL" "IZS" "KRU" "LEN" "LTX" "LTS" "MCI" "MRC" } \\
\text { "NWG" "OPF" "OPG" "PCR" "PEO" "PGE" "PGM" "PCE" "PND" } \\
\text { "PWX" "PRF" "PRT" "RBW" "SNW" "SNX" "SUW" "TRR" "TIM" } \\
\text { "TOW" "TOA" "WWL" "XTP" }\end{array}$ \\
\hline $\mathrm{n}=33$ & $(5)$ & $\begin{array}{l}\text { "11B" "ACG" "ABS" "1AT" "ATL" "ATG" "BAL" "CDR" "COG" } \\
\text { "CMP" "CPS" "DEK" "DVL" "ENP" "ING" "IRL" "IZB" "KTY" } \\
\text { "MAB" "MCR" "OBL" "NVA" "PCX" "PLZ" "PCE" "PDZ" "RPC" } \\
\text { "SEN" "SES" "SUW" "TNX" "TMR" "VTI" }\end{array}$ \\
\hline $\mathrm{n}=32$ & $(6)$ & $\begin{array}{l}\text { "4FM" "ABE" "ALR" "AML" "ABS" "ACP" "BST" "CDR" "EKP" } \\
\text { "ETL" "FGT" "IFI" "IZO" "KER" "KOM" "KRU" "MDI" "MOL" } \\
\text { "MZN" "MSP" "MZA" "OPL" "PBX" "PGE" "PKO" "PXM" "SNK" } \\
\text { "SVRS" "SKH" "TEN" "VTI" "VTL" }\end{array}$ \\
\hline $\mathrm{n}=45$ & (7) & $\begin{array}{l}\text { "ALL" "AMB" "EAT" "ARH" "ACP" "ATD" "BAL" "BOW" "CPD" } \\
\text { "CLN" "CNT" "COG" "CMP" "CPG" "DBC" "ELZ" "EHG" "FGT" } \\
\text { "IDM" "IMC" "IPE" "IZO" "JJO" "KST" "MIR" "MLS" "MOL" } \\
\text { "MSP" "NEU" "NVT" "PEP" "PPS" "PGN" "PHN" "PRF" "PRT" } \\
\text { "IPF" "ZAP" "RBW" "RNC" "TSG" "VGO" "VOT" "VRG" "ZRE" }\end{array}$ \\
\hline $\mathrm{n}=26$ & $(8)$ & $\begin{array}{l}\text { "AGO" "APN" "ARH" "ASE" "BOS" "DAT" "DOM" "EUR" "FSG" } \\
\text { "IZS" "KPL" "KRC" "LTS" "LSI" "MAK" "MFO" "MIR" "MRB" } \\
\text { "MBR" "NET" "NEU" "ODL" "RLP" "ULG" "UCG" "WXF" }\end{array}$ \\
\hline $\mathrm{n}=27$ & $\begin{array}{l}\text { Entire } \\
\text { period }\end{array}$ & $\begin{array}{l}\text { "ARH" "ATM" "BFT" "BST" "BNP" "CDR" "CRM" "IMP" "IPO" } \\
\text { "JSW" "JWC" "KER" "MBR" "MON" "MZA" "OEX" "PCR" "PKP" } \\
\text { "PJP" "TMR" "VGO" "VOT" "VRG" "WAX" "WXF" "WAS" } \\
\text { "WWL" }\end{array}$ \\
\hline
\end{tabular}


Among the optimal portfolios assembled on the basis of data derived from the beginning of the research period (period $1 \& 2$ ) one can notice the advantage of shares of companies belonging to the 'food and drinks' sector. In the two time windows $1 / 31 / 2015$ - 6/30/2016 and 7/31/2015 - 12/31/2016 optimal portfolios include as many as six food industry companies. In subsequent periods, a smaller impact of the WIG-food index can be observed. Whereas companies related to the WIG-construction, WIG-real estate and WIG-banking and finance sectors were reported to have competitive edge over the food industry (WIG-food). Portfolios from the last time windows have an advantage shares belonging to WIG-IT and WIG-construction indexes. In addition it is well worth noting that companies belonging to financial, insurance and brokerage industry take more storage in portfolio. The optimal portfolio for the entire time period includes shares from WIG-clothes, WIG-construction and WIG-real estate indexes.

Constructed portfolios are presented graphically in Fig. 6. The blue points are portfolios drawn for the whole population, while the optimal ones are highlighted with a red point. Only characteristic charts were selected to show.
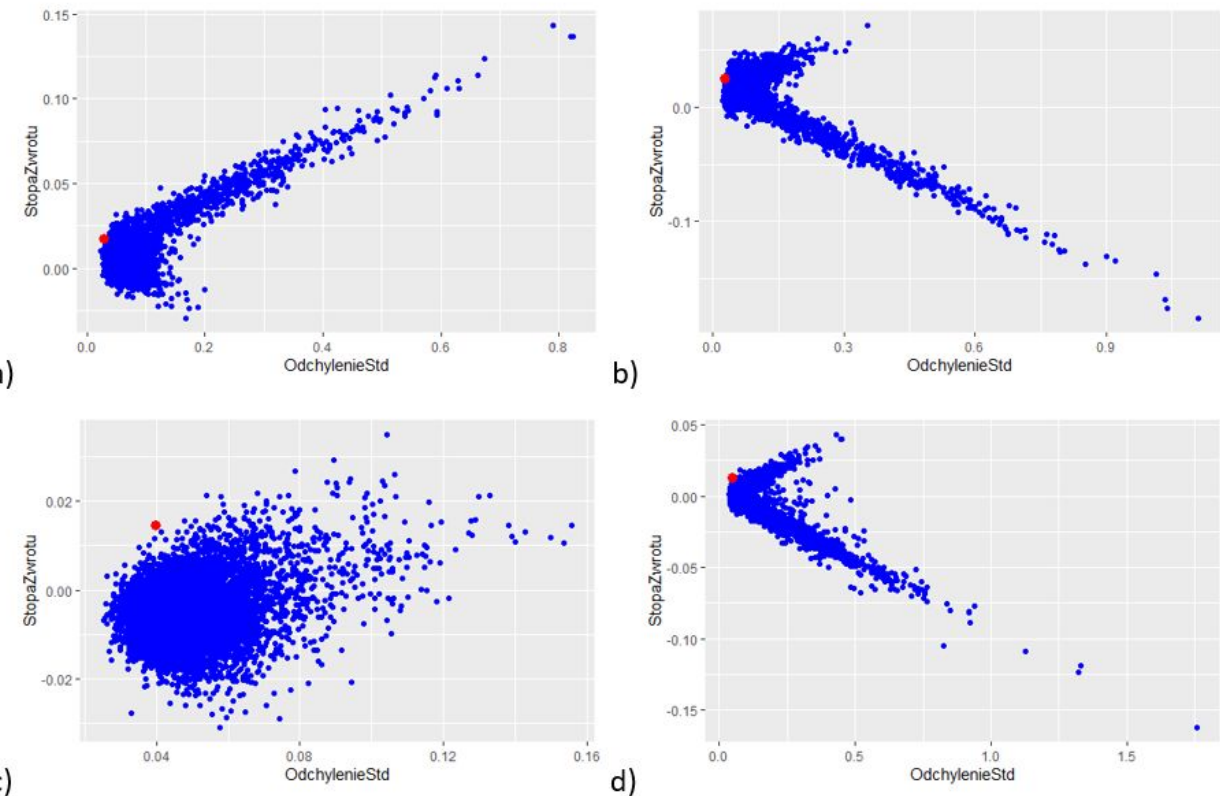

Fig. 6. Optimal portfolios received using formula (11) determined on the basis of randomly selected portfolio of shares; a) time window 1/31/2015 - 6/30/2016; b) time window 1/31/2016 - 6/30/2017; c) time window 1/31/2018 - 30/06/2019; d) the entire time interval; the blue points are the randomized population of 8,000 portfolios, while the optimal point is awarded to the red point; Source: own study

Figure 6 shows investment portfolios assembled randomly at three selected time intervals. The first of these (Fig. 6a) presents portfolios created on the basis of data from the period of time $1 / 31 / 2016-6 / 30 / 2017$. The optimal portfolio determined 
in Figure $6 \mathrm{~b}$ achieved the highest rate of return among all portfolios. Figure 61c, significantly standing out from the others, presents investment portfolios built in the process of searching for the optimal portfolio, which recorded the smallest quotient of the rate of return and the variance. Stock portfolios in Fig. 6c accumulate in one area, which means small deviations from the average risk and the average rate of return in a given period. Figure $6 \mathrm{~d}$ shows investment portfolios determined for the entire data range using randomized methods. As you can see this set of portfolios on the chart (Fig. 6d) already resembles the so-called 'Markowitz Bullet'. The curve obtained after combining all portfolios created using data from the entire period may be similar to the curve of effective portfolios. The portfolio with the highest ratio of the expected rate of return and the variance was marked with a red dot within all charts. Table 3 summarizes the results of optimal portfolios obtained on the basis of the draw. In that cases the quotient of the expected rate of return and the semi-variance (see eq. 12) is taken into account. There are the time windows, number of shares and parameters of optimal portfolio, obtained according to the adaptation function given by equation (12).

Table 3. Optimal portfolios according to ratio of rate of return and semi-variance determined on the basis of a draw in particular time windows and for the entire data range.

The population size is 8,000 randomized portfolios.

\begin{tabular}{|c|c|c|c|c|c|}
\hline \multirow{2}{*}{$\begin{array}{l}\text { Number of } \\
\text { shares } \\
\text { in portfolio }\end{array}$} & \multirow[b]{2}{*}{ Period } & \multirow[b]{2}{*}{$\begin{array}{c}\text { Time } \\
\text { window }\end{array}$} & \multicolumn{3}{|c|}{ Optimal portfolio parameters } \\
\hline & & & Rate of return & $\begin{array}{l}\text { Standard } \\
\text { deviation }\end{array}$ & $\begin{array}{l}\text { Quotient of rate of } \\
\text { return and variance }\end{array}$ \\
\hline $\mathrm{n}=45$ & $(1)$ & $31^{\text {st }}$ Jan $2015-30^{\text {th }}$ Jun 2016 & 0.01725 & 0.04772 & 7.57519 \\
\hline $\mathrm{n}=45$ & $(2)$ & $31^{\text {st }}$ Jul $2015-31^{\text {st }}$ Dec 2016 & 0.01737 & 0.04824 & 7.46402 \\
\hline $\mathrm{n}=40$ & (3) & $31^{\text {st }}$ Jan $2016-30^{\text {th }}$ Jun 2017 & 0.02743 & 0.05066 & 10.68897 \\
\hline $\mathrm{n}=50$ & $(4)$ & $31^{\text {st }}$ Jul $2016-31^{\text {st }}$ Dec 2017 & 0.01309 & 0.03691 & 9.60689 \\
\hline $\mathrm{n}=42$ & $(5)$ & $31^{\text {st }}$ Jan $2017-30^{\text {th }}$ Jun 2018 & 0.02164 & 0.06098 & 5.82042 \\
\hline $\mathrm{n}=33$ & (6) & $31^{\text {st }}$ Jul $2017-31^{\text {st }}$ Dec 2018 & 0.01272 & 0.07107 & 2.51757 \\
\hline $\mathrm{n}=45$ & $(7)$ & $31^{\text {st }}$ Jan $2018-30^{\text {th }}$ Jun 2019 & 0.01471 & 0.06776 & 3.20369 \\
\hline $\mathrm{n}=26$ & $(8)$ & $31^{\text {st }}$ Jul $2018-31^{\text {st }}$ Dec 2019 & 0.01456 & 0.05383 & 5.02469 \\
\hline $\mathrm{n}=27$ & Entire period & $31^{\text {st }} \operatorname{Jan} 2015-31^{\text {st }}$ Mar 2020 & 0.01274 & 0.12160 & 0.86168 \\
\hline
\end{tabular}

Source: own study based on simulations.

The results for optimal portfolios determined on the randomly selected portfolio of shares in particular time windows using equation 12 with semi-variance bear a similarity to the outcomes achieved using the equation 11 with entire variance. Again, the most profitable portfolios (in table 3 marked in bold) were achieved in the time intervals $1 / 31 / 2016-6 / 30 / 2017$ and $7 / 31 / 2016-12 / 31 / 2017$. It is well worth pointing out that the number of companies in the optimal portfolio has changed. The portfolio whose quotient rate of return and semi-variance reached 10.69 is made up of 40 companies and its rate of return was 0.02743 . The least satisfactory results were obtained again by the portfolio (see the last row of Table 3) built on the basis of data from the entire 
study period. His ratio of rate of return and semi-variance, i.e. the objective function, gave a value of 0.86 . The darker background in Table 3 indicates the sixth period, which achieved the second lowest result of the objective function, i.e. 2.52. Among the distinguished one and a half year time windows, this result is the smallest.

The next table (see Table 4) contains the companies from which the best randomized portfolios were assembled in highlighted time windows and for the entire surveyed data range. The optimal stock portfolio compositions from the randomized population using the objective function with semi-variances shown in this table do not differ significantly from the corresponding portfolio sets using objective function with variances. Still in the portfolios built in time windows $1 / 31 / 2015-6 / 30 / 2016$ and $7 / 31 / 2015-12 / 31 / 2016$ companies from the food sector (WIG-food index) are domineering. In later periods, the number of companies from the WIG-banking index and those conducting investment activities was gradually increasing. The stock portfolios compositions created in time windows has been dominated by companies from the WIG-real estate index or WIG-construction index since 2018. However, it should be noted that these are randomized portfolios, and the set of the most optimal portfolios in individual time windows can be a clear justification for the good impact of portfolio diversification. Constructed portfolios are likely to effectively reflect the temporary changes in the economic situation on the Polish market.

Table 4. Stock optimal portfolio compositions obtained from the randomized population in a given period using the objective function with semi-variance

\begin{tabular}{|c|c|c|}
\hline $\begin{array}{c}\text { Number of } \\
\text { shares } \\
\text { in portfolio }\end{array}$ & $\begin{array}{c}\text { Time } \\
\text { window }\end{array}$ & Stock portfolio composition \\
\hline $\mathrm{n}=45$ & (1) & $\begin{array}{l}\text { "AGO" "AWM" "ALR" "AMB" "AMC" "ATC" "ASM" "ABS" "AST" } \\
\text { "ATP" "BST" "BIK" "BIO" "BOS" "EFK" "ELT" "EMT" "ENA" } \\
\text { "GRN" "IDA" "IFI" "KER" "KTY" "KOM" "LSI" "MOJ" "MZN" } \\
\text { "MZA" "OEX" "OPM" "OBL" "OVO" "PCR" "PPS" "PKN" "PKO" } \\
\text { "PKP" "RMK" "SFG" "SKH" "SPH" "TMR" "URS" "WWL" "ZRE" }\end{array}$ \\
\hline $\mathrm{n}=45$ & $(2)$ & $\begin{array}{l}\text { "AGO" "AWM" "ALR" "AMB" "AMC" "ATC" "ASM" "ABS" "AST" } \\
\text { "ATP" "BST" "BIK" "BIO" "BOS" "EFK" "ELT" "EMT" "ENA" } \\
\text { "GRN" "IDA" "IFI" "KER" "KTY" "KOM" "LSI" "MOJ" "MZN" } \\
\text { "MZA" "OEX" "OPM" "OBL" "OVO" "PCR" "PPS" "PKN" "PKO" } \\
\text { "PKP" "RMK" "SFG" "SKH" "SPH" "TMR" "URS" "WWL" "ZRE" }\end{array}$ \\
\hline $\mathrm{n}=40$ & (3) & $\begin{array}{l}\text { "ALI" "ASM" "ATS" "BAH" "BOW" "BMC" "CPA" "CCC" "CPL" } \\
\text { "CPS" "ECH" "ELB" "ERG" "EST" "GTN" "HEL" "HRS" "IMP" } \\
\text { "ING" "INF" "JJO" "LAB" "MXC" "MRC" "MEX" "MIL" "MOJ" } \\
\text { "OPF" "PEO" "PSW" "PLW" "RBW" "SES" "SHG" "SNX" "TRR" } \\
\text { "U2K" "WXF" "WOJ" "ZWC" }\end{array}$ \\
\hline 50 & (4) & $\begin{array}{l}\text { "ALR" "ARC" "ASM" "ABS" "ATP" "BAH" "BDZ" "BNP" "BBT" } \\
\text { "DBC" "DEK" "DNP" "DPL" "EDI" "EEX" "ELT" "IDA" "IMP" } \\
\text { "INC" "INK" "IRL" "IZS" "KRU" "LEN" "LTX" "LTS" "MCI" "MRC" } \\
\text { "NWG" "OPF" "OPG" "PCR" "PEO" "PGE" "PGM" "PCE" "PND" } \\
\text { "PWX" "PRF" "PRT" "RBW" "SNW" "SNX" "SUW" "TRR" "TIM" } \\
\text { "TOW" "TOA" "WWL" "XTP" }\end{array}$ \\
\hline
\end{tabular}


Table 4. (cont'd)

\begin{tabular}{|c|c|c|}
\hline $\begin{array}{l}\text { Number of } \\
\text { shares } \\
\text { in portfolio }\end{array}$ & $\begin{array}{c}\text { Time } \\
\text { window }\end{array}$ & Stock portfolio composition \\
\hline $\mathrm{n}=42$ & $(5)$ & $\begin{array}{l}\text { "4FM" "AWM" "ATP" "BAL" "BDZ" "BFT" "CCC" "CDR" "CPD" } \\
\text { "DCR" "EFK" "EMT" "FMF" "GPW" "GCN" "IIA" "INF" "IPE" } \\
\text { "JJO" "KTY" "MBK" "MON" "MSW" "OPG" "OBL" "BKM" "PEM" } \\
\text { "PPS" "PLW" "PCE" "PND" "PRI" "SAN" "SEL" "SES" "SVRS" } \\
\text { "SKA" "STX" "TNX" "TMR" "TIM" "WXF" }\end{array}$ \\
\hline $\mathrm{n}=33$ & (6) & $\begin{array}{l}\text { "11B" "ACG" "ABS" "1AT" "ATL" "ATG" "BAL" "CDR" "COG" } \\
\text { "CMP" "CPS" "DEK" "DVL" "ENP" "ING" "IRL" "IZB" "KTY" } \\
\text { "MAB" "MCR" "OBL" "NVA" "PCX" "PLZ" "PCE" "PDZ" "RPC" } \\
\text { "SEN" "SES" "SUW" "TNX" "TMR" "VTI" }\end{array}$ \\
\hline $\mathrm{n}=45$ & (7) & $\begin{array}{l}\text { "ALL" "AMB" "EAT" "ARH" "ACP" "ATD" "BAL" "BOW" "CPD" } \\
\text { "CLN" "CNT" "COG" "CMP" "CPG" "DBC" "ELZ" "EHG" "FGT" } \\
\text { "IDM" "IMC" "IPE" "IZO" "JJO" "KST" "MIR" "MLS" "MOL" } \\
\text { "MSP" "NEU" "NVT" "PEP" "PPS" "PGN" "PHN" "PRF" "PRT" } \\
\text { "IPF" "ZAP" "RBW" "RNC" "TSG" "VGO" "VOT" "VRG" "ZRE" }\end{array}$ \\
\hline $\mathrm{n}=26$ & $(8)$ & $\begin{array}{l}\text { "AGO" "APN" "ARH" "ASE" "BOS" "DAT" "DOM" "EUR" "FSG" } \\
\text { "IZS" "KPL" "KRC" "LTS" } \\
\text { "LSI" "MAK" "MFO" "MIR" "MRB" "MBR" "NET" "NEU" "ODL" } \\
\text { "RLP" "ULG" "UCG" "WXF" }\end{array}$ \\
\hline $\mathrm{n}=27$ & $\begin{array}{l}\text { Entire } \\
\text { period }\end{array}$ & $\begin{array}{l}\text { "ARH" "ATM" "BFT" "BST" "BNP" "CDR" "CRM" "IMP" "IPO" } \\
\text { "JSW" "JWC" "KER" "MBR" "MON" "MZA" "OEX" "PCR" "PKP" } \\
\text { "PJP" "TMR" "VGO" "VOT" "VRG" "WAX" "WXF" "WAS" "WWL" }\end{array}$ \\
\hline
\end{tabular}

Source: own study based on simulations.

The received portfolios have been shown graphically in Figure 7. Again, the blue points are drawn portfolios, while the optimal point is marked with a red point. Only the most characteristic ones were selected out of all the 9 charts received. This figure (Fig. 7) relates to randomized stock portfolios compositions created by applying objective function (12) with semi-variance in three selected time intervals and for the entire data window. The first period (i.e. data from $1 / 31 / 2016-6 / 31 / 2017$ ) has been illustrated in figure $7 \mathrm{a}$. The optimal portfolio determined in Figure $7 \mathrm{~b}$ achieved the highest value of the ratio rate of return and the semi-variance (value 10.69). Figure 7c, significantly standing out from the others, presents investment portfolios assembled in the process of searching for the optimal portfolio from the data from $1 / 31 / 2018$ to $30 / 06 / 2019$, which recorded one of the smallest quotients of the rate of return and the semi-variance (value 3.2). Again investment portfolios in Figure 7c accumulates in one area, which refers to small deviations from the average risk and average rate of return in a given period. Figure $7 \mathrm{~d}$ shows portfolios determined for the entire data range by using randomized methods and the objective function with semi-variance. The portfolio with the highest ratio of the expected rate of return and semi-variance was marked with a red dot on all charts. 
a)

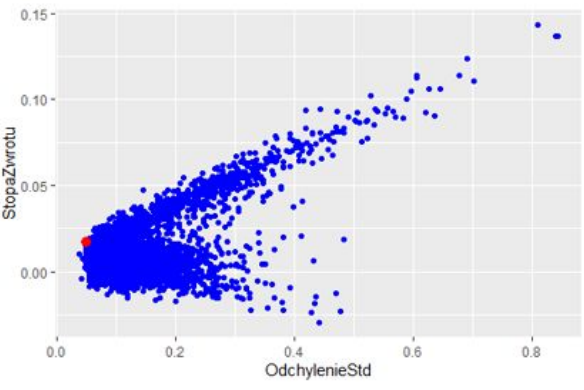

b)
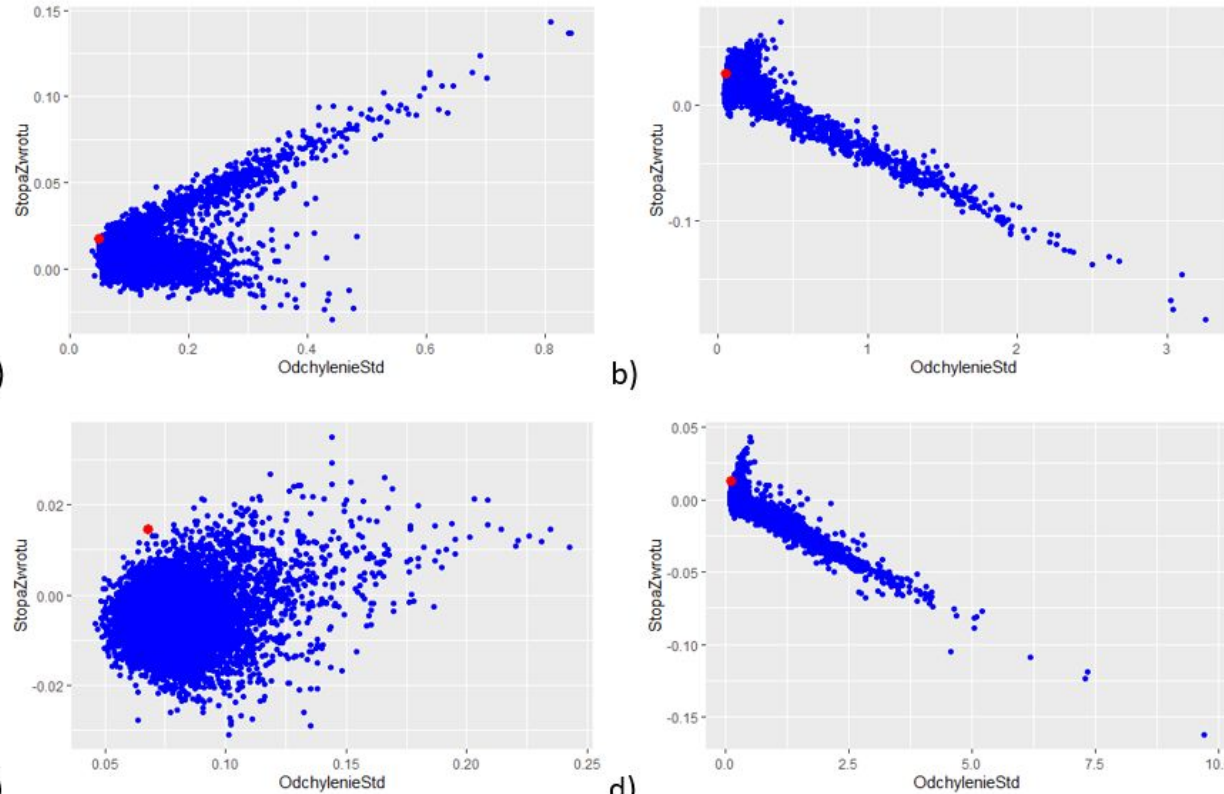

d)

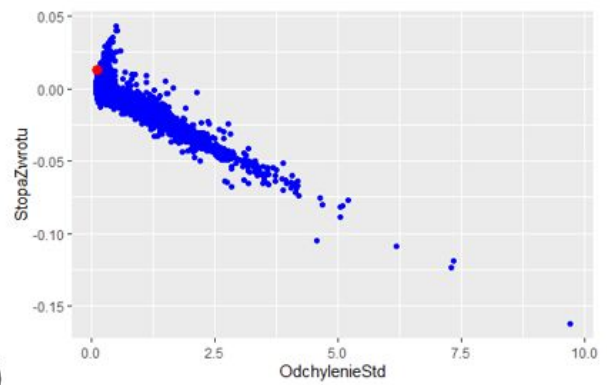

Fig. 7. Optimal portfolios using objective function (eq 12) with semi-variance based on a draw; a) time window 1/31/2015 - 6/30/2016; b) time window 1/31/2016 6/31/2017; c) time window 1/31/2018 - 30/06/2019; d) the entire data interval; blue points is a randomized population of 8,000 portfolios, while the optimal portfolio is distinguished by the red point; Source: own study

\subsection{Portfolios received by using a genetic algorithm}

Similarly, to the presented optimal randomized portfolios, the following tables collected portfolios that were assembled as a result of the application of the discussed genetic algorithm. The generated initial population consisted of 3,000 mixed distribution portfolios. All portfolios in the initial population were ordered according to the indicated objective function (equation 11 and 12). Then, genetic operations were used among the 1000 best individuals. The mechanism of the tournament was used to choose parents. Two crossover operators and two mutation operators were used to generate the child population. After generating 1000 individuals from the progeny population, the selection of the best adapted individuals followed. The number of selections was set at 50 due to time constraints. The average waiting time for results was about 7 minutes.

Optimal portfolios, taking into account the types of crossover operation and mutations determined by using the adaptation function based on variance (Eq. 11) are summarized in Tables 5 and 6 below. Among the optimal portfolios assembled as a result of the genetic algorithm with the selection function from formula (11), the highest rate of return was obtained for a portfolio (highlighted in Table 5 in bold) composed of 33 companies from the third period. According to the quotient of the 
rate of return and the variance, the algorithm using the first method of crossing over individuals and the first method of mutation gave better results. The lowest standard deviation has the portfolio from the first period consisting of 39 items (put in bold in Table 5) obtained as a result of using the first crossover operator and the first method of mutation. This portfolio also has the highest quotient rate of return and the variance. The best rate of return obtained from an optimal portfolio built using a genetic algorithm is at the same level as the rate of return received at random, but the standard deviation is definitely smaller here.

The lowest rate of return was received in the sixth and eighth periods. The sixth period looks like a period of market changes, while the seventh and eighth periods are characterized by some stability in building up portfolios. Due to randomized accumulation in one area, it can be said that they are characterized by small deviations from average risk and small deviations of the expected rate of return in a given period.

Table 5. Parameters of optimal portfolios obtained on the basis of a genetic algorithm; selection function as the quotient of the rate of return and the variance (equation 11).

\begin{tabular}{|c|c|c|c|c|c|}
\hline \multirow{2}{*}{$\begin{array}{l}\text { Crossover } \\
\text { and } \\
\text { mutation }\end{array}$} & \multirow{2}{*}{$\begin{array}{l}\text { Number of } \\
\text { shares } \\
\text { in portfolio }\end{array}$} & \multirow[b]{2}{*}{$\begin{array}{c}\text { Time } \\
\text { window }\end{array}$} & \multicolumn{3}{|c|}{ Optimal portfolio parameters } \\
\hline & & & Rate of return & $\begin{array}{l}\text { Standard } \\
\text { deviation }\end{array}$ & $\begin{array}{l}\text { Quotient of rate of } \\
\text { return and variance }\end{array}$ \\
\hline K1 M1 & $\mathrm{n}=39$ & $31^{\text {st }}$ Jan $2015-30^{\text {th }}$ Jun 2016 & 0.01690 & 0.00272 & 2276.47310 \\
\hline K2 M2 & $\mathrm{n}=27$ & $31^{\text {st }}$ Jan $2015-30^{\text {th }}$ Jun 2016 & 0.02121 & 0.00405 & 1295.42456 \\
\hline K1 M2 & $\mathrm{n}=34$ & $31^{\text {st }}$ Jul $2015-31^{\text {st }}$ Dec 2016 & 0.02117 & 0.00490 & 880.94050 \\
\hline K2 M1 & $\mathrm{n}=34$ & $31^{\text {st }}$ Jul $2015-31^{\text {st }}$ Dec 2016 & 0.02061 & 0.00640 & 503.68092 \\
\hline K1 M1 & $\mathrm{n}=43$ & $31^{\text {st }}$ Jan $2016-30^{\text {th }}$ Jun 2017 & 0.01274 & 0.00463 & 594.13043 \\
\hline K2 M2 & $\mathrm{n}=51$ & $31^{\text {st }}$ Jan $2016-30^{\text {th }}$ Jun 2017 & 0.01450 & 0.00435 & 767.50806 \\
\hline K1 M1 & $\mathrm{n}=33$ & $31^{\text {st }}$ Jul $2016-31^{\text {st }}$ Dec 2017 & 0.02444 & 0.00492 & 1008.16693 \\
\hline K2 M2 & $\mathrm{n}=46$ & $31^{\text {st }}$ Jul $2016-31^{\text {st }}$ Dec 2017 & 0.02883 & 0.00786 & 466.13260 \\
\hline K1 M1 & $\mathrm{n}=55$ & $31^{\text {st }}$ Jan $2017-30^{\text {th }}$ Jun 2018 & 0.01835 & 0.00840 & 260.10111 \\
\hline K2 M2 & $\mathrm{n}=41$ & $31^{\text {st }}$ Jan $2017-30^{\text {th }}$ Jun 2018 & 0.01597 & 0.00753 & 281.33360 \\
\hline K1 M1 & $\mathrm{n}=42$ & $31^{\text {st }}$ Jul $2017-31^{\text {st }}$ Dec 2018 & 0.01580 & 0.00813 & 206.83375 \\
\hline K2 M2 & $\mathrm{n}=43$ & $31^{\text {st }}$ Jul $2017-31^{\text {st }}$ Dec 2018 & 0.02048 & 0.01179 & 147.43574 \\
\hline K1 M1 & $\mathrm{n}=26$ & $31^{\text {st }}$ Jan $2018-30^{\text {th }}$ Jun 2019 & 0.02080 & 0.00747 & 372.35982 \\
\hline K2 M2 & $\mathrm{n}=42$ & $31^{\text {st }}$ Jan $2018-30^{\text {th }}$ Jun 2019 & 0.01740 & 0.01114 & 140.16481 \\
\hline K1 M1 & $\mathrm{n}=29$ & $31^{\text {st }}$ Jul $2018-31^{\text {st }}$ Dec 2019 & 0.01580 & 0.00813 & 238.95217 \\
\hline K2 M2 & $\mathrm{n}=38$ & $31^{\text {st }}$ Jul $2018-31^{\text {st }}$ Dec 2019 & 0.01859 & 0.00592 & 530.90886 \\
\hline K1 M1 & $\mathrm{n}=50$ & $31^{\text {st }}$ Jan $2015-31^{\text {st }}$ Mar 2020 & 0.01279 & 0.01982 & 32.58463 \\
\hline K2 M1 & $\mathrm{n}=45$ & $31^{\text {st }}$ Jan $2015-31^{\text {st }}$ Mar 2020 & 0.01226 & 0.02064 & 28.79258 \\
\hline
\end{tabular}

Source: own study based on simulations. 
Table 6. Stock optimal portfolio composition received from the genetic algorithm in a given period using a selection function with variances (eq. 11)

\begin{tabular}{|c|c|c|c|}
\hline $\begin{array}{l}\text { Crossover } \\
\text { and } \\
\text { mutation }\end{array}$ & $\begin{array}{c}\text { Number of } \\
\text { shares } \\
\text { in portfolio }\end{array}$ & $\begin{array}{c}\text { Time } \\
\text { window }\end{array}$ & Stock portfolio composition \\
\hline K1 M1 & $\mathrm{n}=39$ & (1) & $\begin{array}{l}\text { "ART" "ATP" "BDZ" "BST" "BIK" "CEZ" "DGA" "DOM" } \\
\text { "ECH" "ENP" "EST" "FGT" "HMI" "IRL" "IZO" "IZS" } \\
\text { "KER" "KTY" "KGN" "LKD" "MZA" "NEU" "NTU" } \\
\text { "NVT" "OBL" "PCR" "PHN" "PWX" "POZ" "RLP" "SES" } \\
\text { "SPH" "TBL" "TSG" "TOW" "VGO" "VIN" "VTL" "WOJ" }\end{array}$ \\
\hline K2 M2 & $\mathrm{n}=27$ & $(1)$ & $\begin{array}{l}\text { "BIK" "BBT" "BSC" "ECH" "EFK" "ENP" "GRN" "ATT" } \\
\text { "KRK" "MLS" "MZN" "NET" "NTU" "OPL" "PEM" "PGE" } \\
\text { "PRT" "RON" "SET" "SFG" "SUW" "SWD" "TBL" "TOW" } \\
\text { "VVD" "WAS" "YOL" }\end{array}$ \\
\hline K1 M2 & $\mathrm{n}=34$ & $(2)$ & $\begin{array}{l}\text { "11B" "AMB" "ATC" "ATP" "BIO" "BDX" "CMR" "ECH" } \\
\text { "ENP" "EST" "GTC" "HEL" "IFI" "JJO" "KPD" "LTS" } \\
\text { "MAK" "MXC" "MWT" "NTU" "PKO" "PKP" "PLW" } \\
\text { "RBC" "SWG" "SLV" "SET" "SKT" "STF" "SWD" "TNX" } \\
\text { "TLX" "TBL" "ULG" }\end{array}$ \\
\hline K2 M1 & $\mathrm{n}=34$ & $(2)$ & $\begin{array}{l}\text { "AML" "ASM" "ATP" "BIK" "CDR" "ECH" "ENT" "EST" } \\
\text { "FER" "GTC" "HEL" "IDM" "GKI" "IMP" "JJO" "KRK" } \\
\text { "MXC" "MDI" "MRC" "MFO" "MZA" "NTU" "ODL" } \\
\text { "PND" "PRM" "RAF" "SNK" "SEL" "SFG" "TLX" "TBL" } \\
\text { "TRK" "TEN" "ZUE" }\end{array}$ \\
\hline K1 M1 & $\mathrm{n}=43$ & (3) & $\begin{array}{l}\text { "AGT" "AMB" "ARH" "BST" "BRS" "CDR" "DNP" "ECH" } \\
\text { "EMT" "ELZ" "EST" "EUR" "FRO" "GRN" "HEL" "IDA" } \\
\text { "IDM" "IFI" "IZB" "JJO" "KGN" "KMP" "KRK" "LTX" } \\
\text { "LBT" "MXC" "MIL" "NET" "NEU" "NTU" "OVO" "PCR" } \\
\text { "PGN" "PKN" "PLW" "PZU" "SPH" "STX" "STF" "TRR" } \\
\text { "TOA" "TRN" "XTP" }\end{array}$ \\
\hline K2 M2 & $\mathrm{n}=51$ & $(3)$ & $\begin{array}{l}\text { "ALL" "AAT" "AST" "BST" "BIK" "CDR" "CDL" "DAT" } \\
\text { "DNP" "ECH" "EEX" "ENP" "ENA" "ENE" "ENT" "EGS" } \\
\text { "EST" "GRN" "GTC" "HEL" "I2D" "IDA" "IDM" "IFI" } \\
\text { "IMC" "IPL" "IZS" "KMP" "KPD" "KRU" "LEN" "LBT" } \\
\text { "LTS" "MAK" "MXC" "NEU" "NTU" "NVT" "ORN" "NVA" } \\
\text { "PCX" "PGN" "PRI" "RAF" "SFG" "SKT" "SKL" "SPH" } \\
\text { "SUW" "UNT" "WAX" }\end{array}$ \\
\hline K1 M1 & $\mathrm{n}=33$ & $(4)$ & $\begin{array}{l}\text { "AMB" "AMC" "BST" "CCC" "CDR" "CEZ" "DBC" "DEK" } \\
\text { "DNP" "ENE" "ETL" "IMC" "GKI" "IND" "INF" "JJO" } \\
\text { "MOL" "MON" "NTU" "OPG" "PCR" "PBX" "PSW" } \\
\text { "PLW" "PJP" "PZU" "R22" "SEK" "SFG" "TLX" "VGO" } \\
\text { "VOT" "WLT" }\end{array}$ \\
\hline K2 M2 & $\mathrm{n}=46$ & (4) & $\begin{array}{l}\text { "AGT" "ACP" "ATM" "BAH" "BFT" "BST" "CEZ" "CPS" } \\
\text { "DCR" "DNP" "EST" "GRN" "IFI" "IMC" "GKI" "INL" } \\
\text { "LTS" "LPP" "LBW" "MCI" "MRC" "MFO" "NTU" "NVT" } \\
\text { "OPG" "OBL" "OTS" "PCR" "PPS" "PGO" "PRI" "PRM" } \\
\text { "PRT" "R22" "RBW" "RPC" "SNK" "SPL" "SKL" "SOL" } \\
\text { "SPH" "SHG" "SUW" "TOA" "VIN" "VRG" }\end{array}$ \\
\hline
\end{tabular}


Table 6. (cont'd)

\begin{tabular}{|c|c|c|c|}
\hline K2 M2 & $\mathrm{n}=41$ & (5) & $\begin{array}{l}\text { "4FM" "ARC" "ATP" "BIK" "CPA" "CPD" "CEZ" "CIE" "DBC" } \\
\text { "DNP" "ENT" "EAH" "ETL" "IFI" "IMC" "INP" "INK" "IPO" } \\
\text { "JJO" "K2I" "KVT" "MAK" "MGT" "MCI" "NTU" "OEX" } \\
\text { "OPG" "ORN" "PBX" "IPF" "PZU" "R22" "SEL" "SKT" "SKL" } \\
\text { "SUW" "TMR" "TOA" "VGO" "YOL" "ZWC" }\end{array}$ \\
\hline K1 M1 & $\mathrm{n}=29$ & (6) & $\begin{array}{l}\text { "ASM" "ASE" "CMR" "CPS" "DCR" "EST" "FGT" "FER" } \\
\text { "IPE" "JJO" "KVT" "LKD" "LTS" "LSI" "MAK" "MCP" "MIL" } \\
\text { "OEX" "PPS" "PKN" "PWX" "PRM" "RAF" "SKA" "TMR" } \\
\text { "TSG" "UNT" "WAX" "ZMT" }\end{array}$ \\
\hline K2 M2 & $\mathrm{n}=43$ & (6) & $\begin{array}{l}\text { "AGO" "ALR" "ART" "ASE" "ATD" "BAL" "CNT" "CPL" } \\
\text { "EFK" "ERG" "EST" "EHG" "FSG" "FGT" "FER" "HRS" "HMI" } \\
\text { "INK" "CAR" "KPL" "KRU" "LTX" "MNC" "MIL" "MBR" } \\
\text { "MZA" "NEU" "ORN" "OBL" "OVO" "PCX" "PLZ" "PRT" } \\
\text { "IPF" "RVU" "SVRS" "SKA" "SNX" "TNX" "TMR" "TIM" } \\
\text { "VTI" "WAS" }\end{array}$ \\
\hline K1 M1 & $\mathrm{n}=26$ & (7) & $\begin{array}{l}\text { "AMB" "ATC" "AST" "ATP" "BSC" "DCR" "ENE" "EST" } \\
\text { "FGT" "IMC" "IMS" "INC" "INP" "JJO" "KGL" "KPL" "LTS" } \\
\text { "MGT" "MBR" "OEX" "PGM" "PRT" "RNC" "SNK" "XTP" } \\
\text { "ZRE" }\end{array}$ \\
\hline K2 M2 & $\mathrm{n}=42$ & (7) & $\begin{array}{l}\text { "AMC" "ATC" "ABS" "ATP" "ATS" "BAL" "BSC" "CLN" } \\
\text { "CMR" "CPS" "DCR" "DEK" "DPL" "EST" "FGT" "FTE" } \\
\text { "GTC" "INF" "IPE" "JJO" "KPD" "KRK" "LTS" "MCI" "ODL" } \\
\text { "OEX" "OVO" "PMP" "PCX" "IPF" "RAF" "SNK" "SNW" } \\
\text { "SPH" "SWD" "TNX" "TEN" "UNT" "VIN" "WIK" "WTN" } \\
\text { "ZRE" }\end{array}$ \\
\hline K1 M1 & $\mathrm{n}=$ & (8) & $\begin{array}{l}\text { "ASM" "ASE" "CMR" "CPS" "DCR" "EST" "FGT" "FER" } \\
\text { "IPE" "JJO" "KVT" "LKD" "LTS" "LSI" "MAK" "MCP" "MIL" } \\
\text { "OEX" "PPS" "PKN" "PWX" "PRM" "RAF" "SKA" "TMR" } \\
\text { "TSG" "UNT" "WAX" "ZMT" }\end{array}$ \\
\hline K2 M2 & $\mathrm{n}=38$ & (8) & $\begin{array}{l}\text { "ACG" "AGT" "AMB" "ARH" "ASM" "ASE" "ATD" "ATM" } \\
\text { "APR" "BIK" "DCR" "DVL" "EST" "ETL" "FGT" "FER" "IIA" } \\
\text { "IMS" "JJO" "K2I" "KTY" "KRK" "KVT" "LTX" "LSI" "MAK" } \\
\text { "MCP" "MWT" "OEX" "PMP" "RBW" "SNW" "SEL" "TOW" } \\
\text { "ULG" "UNT" "VTL" "VOX" }\end{array}$ \\
\hline $\mathrm{K} 1 \mathrm{M} 1$ & $\mathrm{n}=50$ & $\begin{array}{l}\text { the } \\
\text { pe }\end{array}$ & $\begin{array}{l}\text { "11B" "AMB" "ASM" "ASE" "ATD" "ATM" "BAL" "BIK" } \\
\text { "CDR" "CNT" "CMP" "DGA" "ECH" "ENP" "EST" "GPW" } \\
\text { "ATT" "GTC" "HMI" "I2D" "IFI" "IIA" "IMC" "GKI" "KMP" } \\
\text { "KOM" "LAB" "LKD" "MAK" "MCI" "MDI" "MIR" "MBR" } \\
\text { "MZN" "OEX" "OPM" "ORN" "BKM" "PJP" "PRT" "RAF" } \\
\text { "RBC" "SEK" "TNX" "TOA" "VTL" "VOX" "WXF" "XTP" } \\
\text { "ZWC" }\end{array}$ \\
\hline $\mathrm{K} 2 \mathrm{M} 2$ & $\mathrm{n}=$ & $\begin{array}{l}\text { the ent } \\
\text { period }\end{array}$ & $\begin{array}{l}\text { "11B" "AMB" "ASM" "ASE" "BAL" "BIK" "BDX" "CDR" } \\
\text { "CNT" "CRM" "CPG" "DAT" "DBC" "EMT" "ENP" "EST" } \\
\text { "GTC" "IFI" "IMC" "IRL" "JJO" "KGL" "KPL" "KMP" "LTS" } \\
\text { "MAK" "MBR" "MZN" "NEU" "NVT" "OAT" "OPM" "ORN" } \\
\text { "OVO" "PMP" "PKP" "PJP" "SNW" "SLV" "SKA" "TNX" } \\
\text { "TMR" "TOA" "VOX" "ZWC" }\end{array}$ \\
\hline
\end{tabular}

Source: own study based on simulations. 
Table 7 gives insight into the set of optimal portfolios obtained from the genetic algorithm in a given period using objective function with variances in individual time windows and for the entire date interval. The application of the genetic algorithm resulted in a change of companies matched to optimal portfolios in particular periods in relation to randomized portfolios. In the first examined period, using the first method of mutation and crossover operator, we can observe the advantage of the share of real estate and construction industries. The dominance of companies from the WIG-construction and WIG-real estate index cannot be observed in the optimal portfolio of the same period using the second type of genetic operations. They make their way to companies from the IT and gaming sectors as well as the financial sector.

Conversely, a different situation occurs in the optimal portfolio constructed in the second time window. The optimal portfolio obtained in the use of the second method of mutation and crossover operator contains the largest number of real estate and construction companies. However, the use of the first type of genetic operations resulted in a portfolio containing only two companies from the aforementioned sectors. In the time windows $1 / 31 / 2016-6 / 30 / 2017$ and $7 / 31 / 2016-12 / 31 / 2017$ portfolio diversification is evenly distributed mainly among companies in the WIG-construction, WIG-real estate, WIG-automobiles \& parts indexes as well as companies conducting financial activities. The portfolio created in the second period of $1 / 31 / 2016-6 / 30 / 2017$ using the second method of mutation and crossover operator has the largest number of companies from the WIG-oil\&gas index among all optimal portfolios created.

The first portfolio created on the basis of data from the time period $1 / 31 / 2017-$ $6 / 30 / 2018$ contains the largest share of companies from the real estate sector, while the second stock portfolio conducting investment, insurance or financial intermediation activities. A characteristic feature of the portfolios created in the sixth period is the significant increase in the number of companies from the IT industry included in the portfolio as opposed to optimal portfolios from other time ranges. Food industry companies have their dominant share in optimal portfolios created on the basis of data from the last two time intervals: $1 / 31 / 2018-6 / 30 / 2019$ and $7 / 31 / 2018-12 / 31 / 2019$. However, construction companies stand out in the portfolio built in the eighth period. Optimal portfolios determined on the basis of the entire research period include the largest number of companies from the WIG-real estate, WIG-IT and WIG-construction indexes. The number of real estate sector companies in the portfolio using the first method of mutation and crossover operation and the entire data period accounts for $18 \%$ of all companies in this portfolio.

The evolutionary algorithm, building subsequent generations, evolves the population leading to the creation of the best adapted individuals. This process can be observed in Figures 8 and 9. Thanks to the color marking of the initial population (green), the extinct population (blue) and the final population (red), the development of the algorithm in the optimal portfolio search process can be observed. The optimal portfolio obtained with the highest quotient of the rate of return and the variance was highlighted in orange.

Figure 8 shows the changes in the portfolio population obtained using the first type crossover operator with the corresponding mutation. 


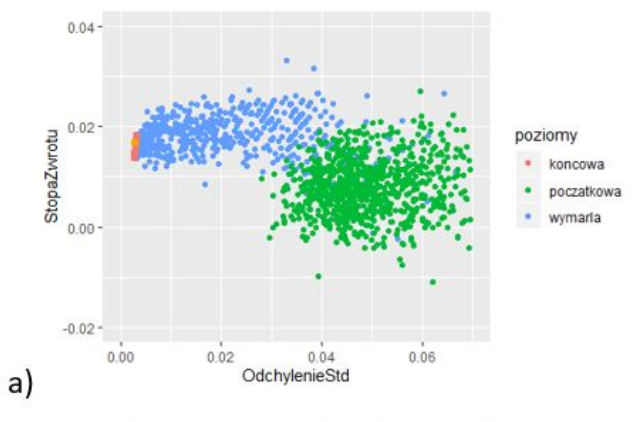

b)
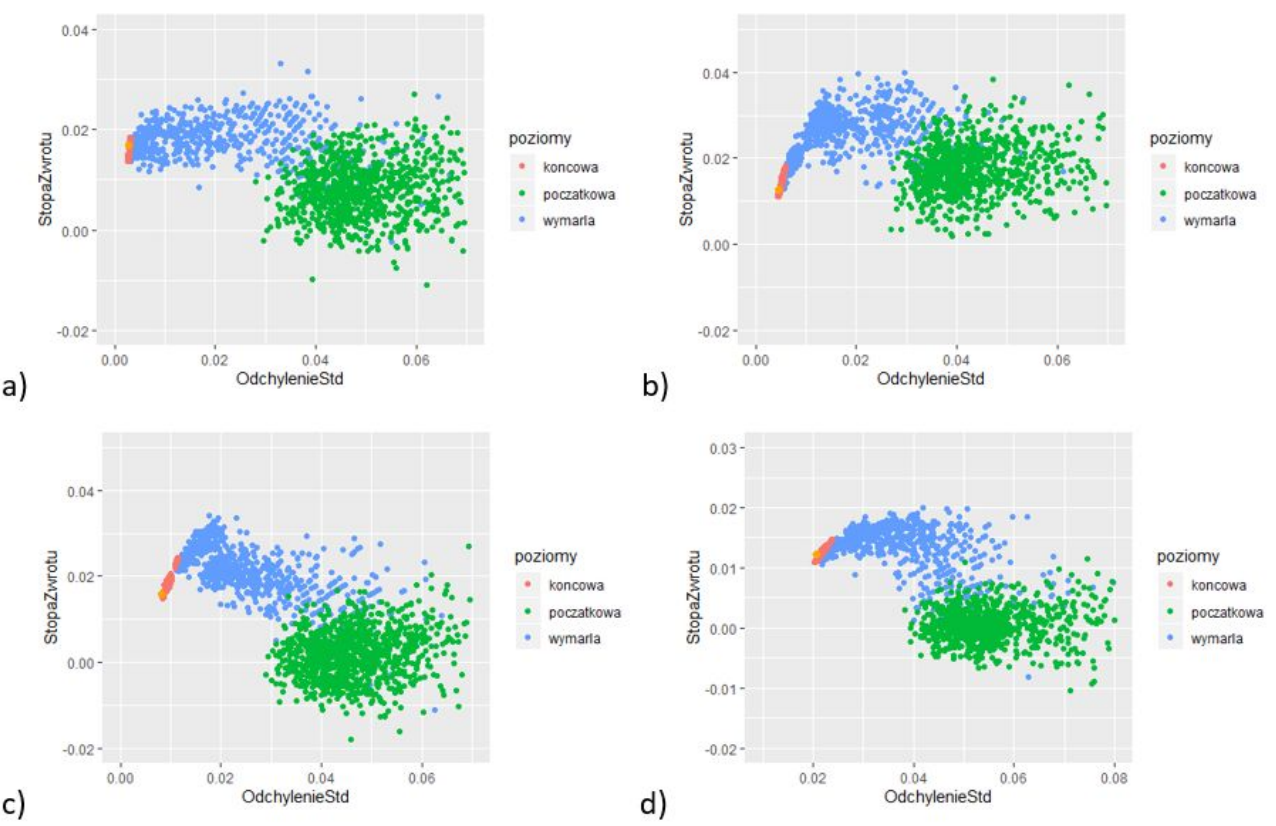

Fig. 8. The transition of the population of portfolios from initial, randomized portfolios (green points), through the extinct population (blue points) to the best portfolios (red points) in the genetic algorithm using objective function with variance and the first type of crossword and mutation; the orange portfolio marks the optimal portfolio; a) portfolios from the period from 1/1/2015 to 6/30/2016; b) portfolios from the third period, i.e. from 1/31/2016 to 7/30/2017; c) portfolios from the eighth period, i.e. from 7/31/2018 to 12/31/2019 d) changes for the entire time window, i.e. from 1/31/2015 to 31/03/2020; Source: own study

Changes in the population of portfolios created using the second type of crossover and mutation are presented in Figure 9. Only characteristic time windows were selected. In both figures ( 8 and 9 ) only selected from those received are shown: first period $(1 / 31 / 2015-6 / 30 / 2016)$, third period $(1 / 31 / 2016-6 / 30 / 2017)$, eighth period $(7 / 31 / 2018-12 / 31 / 2019)$ and changes for the entire time window $(1 / 31 / 2015-$ $3 / 31 / 2020)$.

The second part of this chapter describes the results of the optimal portfolio analysis obtained according to the objective function (equation 12), i.e. using semivariance. Optimal portfolios, taking into account the types of crossword and mutations determined using the adaptation function from formula (12), are summarized in Tables 7 and 8 below.

The highest rate of return among the optimal portfolios obtained as a result of a genetic algorithm with a selection function using a semi-variance (Eq. 12) was achieved for the portfolio (put in bold in Table 7) in the third and fourth periods. These distinguished portfolios consist of 45 or 42 shares, respectively, with shares generated using the first (45 companies) and the second (42 shares) crossover operation and relevant mutations. The lowest standard deviation of 0.00621 was obtained by the 
portfolio (highlighted in Table 7 in bold) from the first period containing 37 items. The best, according to the adaptation function given by Equation (12), obtained an optimal portfolio characterized by a quotient of the rate of return and the semi-variance of 470.94, which is twenty times higher than the case of a randomized portfolio from the same period.

a)
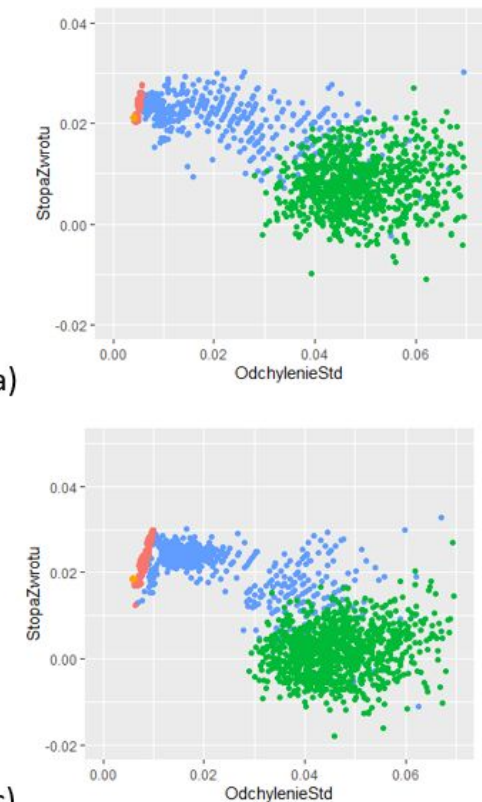

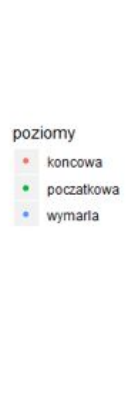

b)
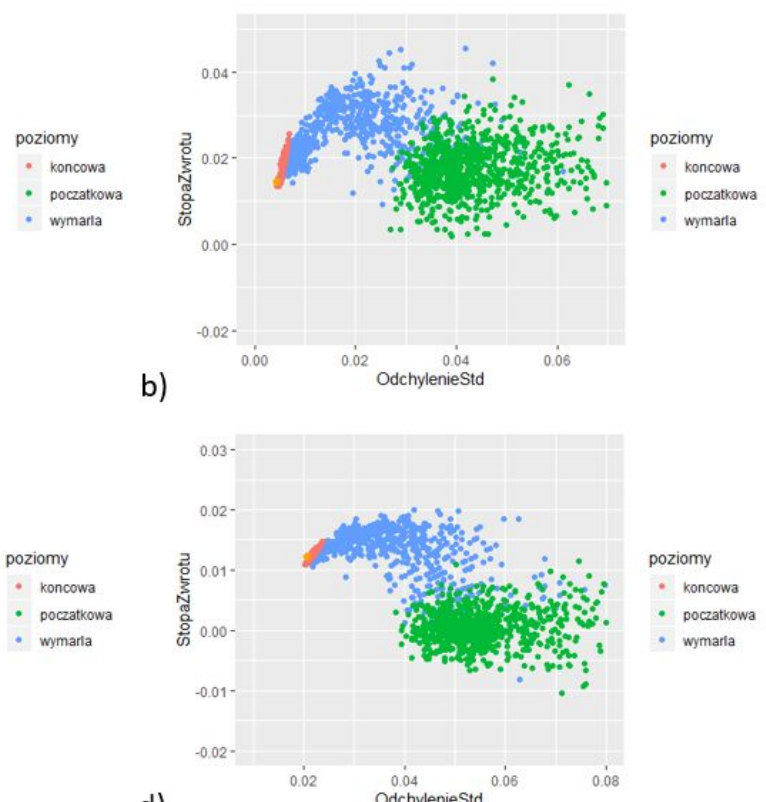

d)

Fig. 9. Portfolio population distribution from initial, randomized portfolios (green points), through extinct population (blue points) to best portfolios (red points) in a genetic algorithm using objective function with variance and a second type of crossover and mutation; the orange portfolio marks the optimal portfolio; a) portfolios from the period from $1 / 1 / 2015$ to $6 / 30 / 2016$; b) portfolios from the third period, i.e. from 1/31/2016 to 6/30/2017; c) portfolios from the eighth period, i.e. from 7/31/2018 to 12/31/2019 'd) changes for the entire time window, i.e. from 1/31/2015 to 31/03/2015; Source: own study

Table 7. Parameters of optimal portfolios obtained on the basis of a genetic algorithm; selection function as the quotient of the rate of return and the semi-variance (equation 12).

\begin{tabular}{|c|c|c|c|c|c|}
\hline \multirow{2}{*}{$\begin{array}{l}\text { Crossover } \\
\text { and } \\
\text { mutation }\end{array}$} & \multirow{2}{*}{$\begin{array}{l}\text { Number of } \\
\text { shares } \\
\text { in portfolio }\end{array}$} & \multirow[b]{2}{*}{$\begin{array}{c}\text { Time } \\
\text { window }\end{array}$} & \multicolumn{3}{|c|}{ Optimal portfolio parameters } \\
\hline & & & Rate of return & $\begin{array}{c}\text { Semi- } \\
\text {-deviations }\end{array}$ & $\begin{array}{l}\text { Quotient of rate of } \\
\text { return and variance }\end{array}$ \\
\hline K1 M1 & $\mathrm{n}=47$ & $31^{\text {st }}$ Jan $2015-30^{\text {th }}$ Jun 2016 & 0.01863 & 0.01007 & 183.56399 \\
\hline $\mathrm{K} 2 \mathrm{M} 2$ & $\mathrm{n}=37$ & $31^{\text {st }}$ Jan $2015-30^{\text {th }}$ Jun 2016 & 0.01818 & 0.00621 & 470.94261 \\
\hline K1 M2 & $\mathrm{n}=44$ & $31^{\text {st }}$ Jul $2015-31^{\text {st }}$ Dec 2016 & 0.01597 & 0.00718 & 309.68626 \\
\hline K2 M1 & $\mathrm{n}=42$ & $31^{\text {st }}$ Jul $2015-31^{\text {st }}$ Dec 2016 & 0.02449 & 0.01340 & 136.42229 \\
\hline
\end{tabular}


Table 7. (cont'd)

\begin{tabular}{|c|c|c|c|c|c|}
\hline \multirow{2}{*}{$\begin{array}{l}\text { Crossover } \\
\text { and } \\
\text { mutation }\end{array}$} & \multirow{2}{*}{$\begin{array}{l}\text { Number of } \\
\text { shares } \\
\text { in portfolio }\end{array}$} & \multirow[b]{2}{*}{$\begin{array}{c}\text { Time } \\
\text { window }\end{array}$} & \multicolumn{3}{|c|}{ Optimal portfolio parameters } \\
\hline & & & Rate of return & $\begin{array}{c}\text { Semi- } \\
\text {-deviations }\end{array}$ & $\begin{array}{l}\text { Quotient of rate of } \\
\text { return and variance }\end{array}$ \\
\hline K1 M1 & $\mathrm{n}=42$ & $31^{\text {st }}$ Jan $2016-30^{\text {th }}$ Jun 2017 & 0.02604 & 0.01319 & 149.67088 \\
\hline K2 M2 & $\mathrm{n}=54$ & $31^{\text {st }}$ Jan $2016-30^{\text {th }}$ Jun 2017 & 0.01272 & 0.00876 & 165.91840 \\
\hline K1 M1 & $\mathrm{n}=46$ & $31^{\text {st }}$ Jul $2016-31^{\text {st }}$ Dec 2017 & 0.02063 & 0.00898 & 256.08080 \\
\hline K2 M2 & $\mathrm{n}=45$ & $31^{\text {st }}$ Jul $2016-31^{\text {st }}$ Dec 2017 & 0.02775 & 0.01580 & 111.22560 \\
\hline K1 M1 & $\mathrm{n}=52$ & $31^{\text {st }}$ Jan $2017-30^{\text {th }}$ Jun 2018 & 0.02013 & 0.01814 & 61.17865 \\
\hline K2 M2 & $\mathrm{n}=44$ & $31^{\text {st }}$ Jan $2017-30^{\text {th }}$ Jun 2018 & 0.01681 & 0.01705 & 57.84202 \\
\hline K1 M1 & $\mathrm{n}=43$ & $31^{\text {st }}$ Jul $2017-31^{\text {st }}$ Dec 2018 & 0.02358 & 0.02391 & 41.26002 \\
\hline K2 M2 & $\mathrm{n}=33$ & $31^{\text {st }}$ Jul $2017-31^{\text {st }}$ Dec 2018 & 0.02042 & 0.02270 & 39.64218 \\
\hline K1 M1 & $\mathrm{n}=35$ & $31^{\text {st }}$ Jan $2018-30^{\text {th }}$ Jun 2019 & 0.01993 & 0.01557 & 82.20398 \\
\hline K2 M2 & $\mathrm{n}=41$ & $31^{\text {st }}$ Jan $2018-30^{\text {th }}$ Jun 2019 & 0.01090 & 0.01254 & 69.29898 \\
\hline K1 M1 & $\mathrm{n}=45$ & $31^{\text {st }}$ Jul $2018-31^{\text {st }}$ Dec 2019 & 0.01914 & 0.01279 & 117.05182 \\
\hline K2 M2 & $\mathrm{n}=37$ & $31^{\text {st }}$ Jul $2018-31^{\text {st }}$ Dec 2019 & 0.02391 & 0.01451 & 113.61452 \\
\hline K1 M1 & $\mathrm{n}=58$ & $31^{\text {st }}$ Jan $2015-31^{\text {st }}$ Mar 2020 & 0.01157 & 0.05257 & 4.18559 \\
\hline K2 M1 & $\mathrm{n}=50$ & $31^{\text {st }}$ Jan $2015-31^{\text {st }}$ Mar 2020 & 0.01079 & 0.05048 & 4.23529 \\
\hline
\end{tabular}

Source: own study based on simulations.

In Table 8, structural changes of the received optimal portfolios can be traced.

Table 8. Stock optimal portfolio composition obtained from the genetic algorithm in a given period using a selection function with semi-variances (Eq. 12)

\begin{tabular}{|c|c|c|c|}
\hline $\begin{array}{c}\text { Crossover } \\
\text { and } \\
\text { mutation }\end{array}$ & $\begin{array}{c}\text { Number of } \\
\text { shares } \\
\text { in portfolio }\end{array}$ & $\begin{array}{c}\text { Time } \\
\text { window }\end{array}$ & Stock portfolio composition \\
\hline K1 M1 & $\mathrm{n}=47$ & (1) & $\begin{array}{l}\text { "ACG" "ALI" "AML" "EAT" "ACP" "BDZ" "BST" "BIK" } \\
\text { "BRS" "DOM" "EKP" "EST" "ETL" "GPW" "IPL" "IMP" } \\
\text { "IND" "INF" "JJO" "KRK" "LRQ" "MAK" "MFO" "MOL" } \\
\text { "MZA" "NEU" "NTU" "NVT" "ODL" "OEX" "OVO" } \\
\text { "BKM" "PEO" "PSW" "PHR" "PJP" "SPL" "TMR" "TBL" } \\
\text { "TIM" "TOW" "VGO" "VVD" "VOX" "XTP" "YOL" } \\
\text { "ZWC" }\end{array}$ \\
\hline K2 M2 & $\mathrm{n}=37$ & (1) & $\begin{array}{l}\text { "AWM" "AML" "ART" "1AT" "BIK" "BSC" "CDL" "CMR" } \\
\text { "EFK" "ENP" "FON" "FTE" "GRN" "HRS" "K2I" "KPL' } \\
\text { "KRU" "MAK" "MCP" "MNC" "MEX" "MFO" "NTU" } \\
\text { "ODL" "PBX" "PEO" "PSW" "PLW" "PGM" "PRF" "ZAP" } \\
\text { "SET" "SKA" "STF" "TBL" "TOW" "WAS" }\end{array}$ \\
\hline
\end{tabular}


Table 8. (cont'd)

\begin{tabular}{|c|c|c|c|}
\hline $\begin{array}{c}\text { Crossover } \\
\text { and } \\
\text { mutation }\end{array}$ & $\begin{array}{c}\text { Number of } \\
\text { shares } \\
\text { in portfolio }\end{array}$ & $\begin{array}{c}\text { Time } \\
\text { window }\end{array}$ & Stock portfolio composition \\
\hline K1 M1 & $\mathrm{n}=44$ & (2) & $\begin{array}{l}\text { "11B" "ACG" "AGO" "AML" "1AT" "BFT" "BMC" "EFK" } \\
\text { "ERG" "EST" "FSG" "GRN" "IMC" "GKI" "IPL" "INC" } \\
\text { "ING" "JJO" "LTS" "MXC" "MBR" "MZN" "NTU" "OEX" } \\
\text { "ORN" "OVO" "PMP" "BKM" "PCX" "PWX" "PRT" } \\
\text { "ZAP" "SAN" "SES" "SET" "SFG" "SKT" "SKA" "TMR" } \\
\text { "TBL" "TSG" "TIM" "WXF" "XTP" }\end{array}$ \\
\hline K2 M2 & $\mathrm{n}=42$ & (2) & $\begin{array}{l}\text { "11B" "ACG" "ADV" "AMB" "AST" "BDZ" "BST" "BIK" } \\
\text { "CMR" "DAT" "DBC" "ECH" "EKP" "ELZ" "EGS" "EST" } \\
\text { "ATT" "GTC" "HEL" "HMI" "IFI" "IMS" "INF" "JJO" } \\
\text { "KER" "LAB" "MAB" "MXC" "MFO" "MOJ" "NTU" } \\
\text { "OAT" "NVA" "PPS" "PKN" "PRT" "RON" "SWG" "TMR" } \\
\text { "TBL" "VVD" "VRG" }\end{array}$ \\
\hline K1 M1 & $\mathrm{n}=42$ & (3) & $\begin{array}{l}\text { "11B" "AGO" "ALL" "ATL" "ATG" "BAH" "BRS" "CDR" } \\
\text { "DOM" "ECH" "ENE" "ERG" "EST" "EHG" "HRS" "IFI" } \\
\text { "ING" "JJO" "KRI" "LRQ" "LTS" "LSI" "MAK" "MXC" } \\
\text { "MBK" "MCP" "MFO" "NTU" "ODL" "OVO" "PCR" } \\
\text { "PGO" "PRM" "PJP" "PRT" "SPL" "SKA" "TOA" "UNI" } \\
\text { "U2K" "URS" "VOT" }\end{array}$ \\
\hline K2 M2 & $\mathrm{n}=54$ & (3) & $\begin{array}{l}\text { "ALL" "AAT" "APN" "BST" "BIK" "CCC" "CDR" "CEZ" } \\
\text { "DEK" "DNP" "EFK" "EEX" "EST" "EUC" "GPW" "HEL" } \\
\text { "HMI" "IDA" "IFI" "GKI" "IMP" "ING" "IRL" "INF" "JJO" } \\
\text { "KGL" "KGN" "KMP" "LTX" "LBT" "MAK" "MXC" "MCI" } \\
\text { "MRC" "MIL" "NTU" "OPL" "OVO" "NVA" "PCR" "PEO" } \\
\text { "PGO" "PRI" "PJP" "RLP" "SES" "SKA" "SOL" "STP" } \\
\text { "STF" "TNX" "TLX" "TOA" "ZUE" }\end{array}$ \\
\hline K1 M1 & $\mathrm{n}=46$ & (4) & $\begin{array}{l}\text { "ACG" "AMB" "ATM" "ATG" "APR" "BNP" "CPA" } \\
\text { "CDR" "CEZ" "CNT" "DEL" "DVL" "DNP" "ECH" "ELB" } \\
\text { "EST" "FRO" "GTC" "IDM" "GKI" "JJO" "K2I" "KPL" } \\
\text { "KRC" "KRI" "LTS" "MCI" "MNC" "MWT" "NET" "NTU" } \\
\text { "ODL" "OPG" "PGE" "PLW" "PRI" "PJP" "PZU" "R22" } \\
\text { "RPC" "RBC" "SKT" "SKA" "TOW" "UCG" "VIN" }\end{array}$ \\
\hline K2 M2 & $\mathrm{n}=45$ & (4) & $\begin{array}{l}\text { "ALI" "APN" "ARC" "AST" "1AT" "ATS" "BSC" "CPS" } \\
\text { "DBC" "DNP" "ELZ" "ENP" "EST" "GRN" "BHW" "HEL" } \\
\text { "HMI" "IDM" "IIA" "GKI" "INC" "JJO" "KTY" "KPL" } \\
\text { "LTX" "MBK" "NTU" "OAT" "OPG" "PMP" "PBX" "PKO" } \\
\text { "PLW" "PRT" "PZU" "R22" "RON" "SEK" "SEL" "SKA" } \\
\text { "SOL" "TNX" "U2K" "WOJ" "XTP" }\end{array}$ \\
\hline K1 M1 & $\mathrm{n}=52$ & (5) & $\begin{array}{l}\text { "11B" "4FM" "ACG" "AMB" "EAT" "ARC" "BAL" "BDZ" } \\
\text { "BSC" "CPA" "CDR" "CEZ" "CPL" "DBC" "DEK" "DEL" } \\
\text { "DGA" "DNP" "ENP" "ERB" "ETL" "GTC" "HRS" "HMI" } \\
\text { "IFI" "IIA" "IMC" "INC" "IRL" "JJO" "JWW" "KPD" } \\
\text { "LKD" "LTS" "MCR" "MIL" "NTU" "OPG" "OBL" "OTM" } \\
\text { "BKM" "PCR" "PLW" "PZU" "R22" "SAN" "SNW" "SFG" } \\
\text { "SPH" "TMR" "TOA" "XTP" }\end{array}$ \\
\hline
\end{tabular}


Table 8. (cont'd)

\begin{tabular}{|c|c|c|c|}
\hline $\begin{array}{c}\text { Crossover } \\
\text { and } \\
\text { mutation }\end{array}$ & $\begin{array}{c}\text { Number of } \\
\text { shares } \\
\text { in portfolio }\end{array}$ & $\begin{array}{c}\text { Time } \\
\text { window }\end{array}$ & Stock portfolio composition \\
\hline K2 M2 & $\mathrm{n}=44$ & (5) & $\begin{array}{l}\text { "4FM" "ACT" "ALL" "ARC" "ABS" "ATG" "CPA" "CEZ' } \\
\text { "CNT" "CPG" "DBC" "DNP" "ENE" "EAH" "ETL" "BHW" } \\
\text { "IIA" "IMC" "GKI" "IND" "INP" "INK" "IRL" "JJO" } \\
\text { "KVT" "LPP" "MGT" "MBK" "MBR" "NTU" "PCR" } \\
\text { "PSW" "PLW" "PRT" "PZU" "R22" "RPC" "SWG" "SUW" } \\
\text { "TRR" "TOA" "WAS" "WTN" "ZMT" }\end{array}$ \\
\hline K1 M1 & $\mathrm{n}=43$ & (6) & $\begin{array}{l}\text { "ACG" "AMB" "EAT" "ASM" "ABS" "ACP" "BAL" "BDZ" } \\
\text { "BSC" "CDR" "CNT" "CMR" "DAT" "DCR" "EAH" "FGT" } \\
\text { "GRN" "HMI" "IMS" "ING" "JJO" "LTS" "MNC" "MIL" } \\
\text { "MRB" "MBR" "MOL" "NET" "NTU" "ODL" "PBX" } \\
\text { "PLW" "PND" "RLP" "SWG" "SLV" "SVRS" "SLZ" "SUW" } \\
\text { "VGO" "VIN" "VOX" "XTP" }\end{array}$ \\
\hline K2 M2 & $\mathrm{n}=33$ & (6) & $\begin{array}{l}\text { "4FM" "AMB" "EAT" "BAL" "BSC" "CEZ" "COG" "DEK" } \\
\text { "ENP" "ENG" "EST" "FGT" "GCN" "IMS" "INF" "JJO" } \\
\text { "KER" "KVT" "LTS" "MOL" "MZA" "OVO" "PRF" "RLP" } \\
\text { "RPC" "SWG" "SVRS" "SME" "SKA" "SNX" "SUW" } \\
\text { "TNX" "TIM" }\end{array}$ \\
\hline K1 M1 & $\mathrm{n}=35$ & (7) & $\begin{array}{l}\text { "AMB" "AMC" "ABS" "ASE" "ATD" "BAL" "CNT" "CMR' } \\
\text { "CPS" "DCR" "DEK" "DNP" "EDI" "EST" "FGT" "FER' } \\
\text { "GTC" "BHW" "JJO" "MDI" "MBR" "NET" "ODL" "OPG" } \\
\text { "IPF" "R22" "RPC" "SES" "SNX" "TMR" "VIN" "VOX" } \\
\text { "XTP" "ZRE" "ZWC" }\end{array}$ \\
\hline K2 M2 & $\mathrm{n}=41$ & (7) & $\begin{array}{l}\text { "AMC" "ATC" "ATP" "ATS" "ATM" "BAL" "CDR" "CMR' } \\
\text { "DCR" "ECH" "EMC" "ENP" "ENA" "EST" "EUR" "FGT" } \\
\text { "FER" "IDM" "ING" "INF" "IZO" "JJO" "KER" "KPL' } \\
\text { "KST" "KRK" "MDI" "MEX" "MLS" "MON" "MSP" "OEX' } \\
\text { "OPM" "PEP" "PPS" "PRT" "PZU" "SKH" "SKL" "SNX' } \\
\text { "TMR" "VRG" "ZEP" "ZWC" }\end{array}$ \\
\hline K1 M1 & $\mathrm{n}=45$ & (8) & $\begin{array}{l}\text { "ABE" "ACG" "ART" "ASM" "ATP" "BAL" "BBD" "BML" } \\
\text { "BNP" "CPG" "DCR" "ENP" "ENT" "EAH" "EST" "FGT" } \\
\text { "IDM" "INF" "IZB" "JJO" "KTY" "KOM" "KST" "KRK" } \\
\text { "LTS" "LSI" "LBW" "MAK" "NWG" "OEX" "PEP" "PHR" } \\
\text { "PXM" "PND" "PRT" "R22" "RAF" "SWG" "SEN" "SME" } \\
\text { "SNX" "TSG" "UNT" "WXF" "ZWC" }\end{array}$ \\
\hline K2 M2 & $\mathrm{n}=37$ & (8) & $\begin{array}{l}\text { "AMB" "BAL" "BIK" "CEZ" "CNT" "DCR" "EST" "ETL" } \\
\text { "FSG" "FGT" "GCN" "IFI" "IMC" "IPE" "JJO" "KST" } \\
\text { "KRC" "KRK" "LSI" "MCI" "NEU" "NWG" "OPL" "OVO" } \\
\text { "BKM" "PCX" "RNC" "RMK" "SLV" "SFG" "SKA" "SWD" } \\
\text { "TNX" "UCG" "VIN" "VRG" "WXF" }\end{array}$ \\
\hline
\end{tabular}


Table 8. (cont'd)

\begin{tabular}{|c|c|c|c|}
\hline $\begin{array}{c}\text { Crossover } \\
\text { and } \\
\text { mutation }\end{array}$ & $\begin{array}{c}\text { Number of } \\
\text { shares } \\
\text { in portfolio }\end{array}$ & $\begin{array}{c}\text { Time } \\
\text { window }\end{array}$ & Stock portfolio composition \\
\hline K1 M1 & $\mathrm{n}=58$ & $\begin{array}{l}\text { Entire } \\
\text { period }\end{array}$ & $\begin{array}{l}\text { "11B" "ACG" "AMB" "APN" "ATC" "ASM" "ACP" "ASE" } \\
\text { "1AT" "ATL" "APR" "BFT" "BRS" "BSC" "BDX" "CDR" } \\
\text { "CEZ" "CNT" "CMR" "CPG" "DAT" "DCR" "DVL" "DOM" } \\
\text { "EMC" "ENP" "EST" "ETL" "GTC" "IIA" "IMC" "IPO" } \\
\text { "KRK" "LSI" "MAK" "MCI" "MRC" "MBR" "MZN" "OEX" } \\
\text { "OPM" "ORN" "NVA" "PCR" "PLW" "PRF" "PJP" "RBW" } \\
\text { "RNK" "RPC" "RVU" "SNK" "SKA" "TIM" "TOA" "VOX" } \\
\text { "WIK" "ZWC" }\end{array}$ \\
\hline K2 M2 & $\mathrm{n}=50$ & $\begin{array}{l}\text { Entire } \\
\text { period }\end{array}$ & $\begin{array}{l}\text { "ARH" "ASM" "ABS" "ASE" "APR" "BFT" "BST" "CDR" } \\
\text { "CNT" "CPG" "DCR" "DOM" "ECH" "ERG" "EST" "ETL" } \\
\text { "HMI" "IFI" "IMC" "GKI" "IRL" "KMP" "KRK" "MAK" } \\
\text { "MNC" "MCR" "MBR" "MOL" "NEU" "CNG" "ODL" } \\
\text { "OPN" "OPM" "OBL" "PCX" "PBX" "PPS" "PSW" "PLW" } \\
\text { "PRF" "PJP" "RON" "SLV" "TMR" "VGO" "VOX" "WAX" } \\
\text { "WXF" "WAS" "ZWC" }\end{array}$ \\
\hline
\end{tabular}

Source: own study based on simulations.

The companies included in individual optimal portfolios obtained from the genetic algorithm in a given period using semi-variance are presented in Table 8. All optimal portfolios presented in this table have also been diversified in terms of the different industries of enterprises in the portfolio. In each optimal portfolio, assets belonging to at least half of the eleven industry indexes can be distinguished. In the first period examined, assets in the construction, mining, real estate and financial sectors gain definite advantage.

An balanced share of companies from various sectors can be observed in the period $7 / 31 / 2015-12 / 31 / 2016$ using the first crossover operator and relevant mutation. In turn, in the same time window, when using the second method of crossover and mutation, a significant advantage of the share of companies from the WIG-real estate and WIGfood index can be observed. Further portfolios contain a high share of companies from the construction industry as well as financial, insurance and investment consulting. In the periods $7 / 31 / 2016-12 / 31 / 2017$ and $1 / 31 / 2017-6 / 31 / 2018$ companies from the real estate, construction and financial sectors have the largest roles in the portfolio. In the time windows $7 / 31 / 2017-12 / 31 / 2018$ and $1 / 31 / 2018-6 / 30 / 2019$, assets from the real estate and construction sectors continue to prevail, the position of IT companies in the portfolio has also strengthened.

Portfolios from the eighth period did not record a significant advantage of companies belonging to one of the eleven industry indexes. The share of 3 to 5 assets from the industry was achieved by companies in the transport and automotive sectors (WIG-automobiles \& parts), clothing (WIG-clothes), food (WIG-food), construction (WIG-construction) and real estate (WIG-real estate). Using data from the entire study 
period, optimal portfolios of 50 and 58 different assets were created. Among all companies, most of them belong to the WIG-IT, WIG-real estate and WIG-construction indexes.

Similarly, to the genetic algorithm for variance, charts for selected evolutionary changes were created. Illustrations of population changes for selected optimal portfolios from Tables 7 and 8 are shown in Figures 10 and 11. The evolution process has been again presented, i.e. moving from portfolios from the initial population (green), through the extinct population (blue) all the way to the final population (hardly visible in red). The estimated optimal portfolio is marked with an orange point.

Figure 10a shows the most well-adapted regarding the selection function portfolio. Figure 10d presents the portfolios created on the basis of data derived from the whole period. In the chart $10 \mathrm{~b}$ showing the transition from the initial population to the final population in the time window $7 / 31 / 2015-12 / 31 / 2016$ using the first method of mutation and the first crossover operator, the process of gradual displacement of the potential profitability line of investments is particularly clearly observed.

a)
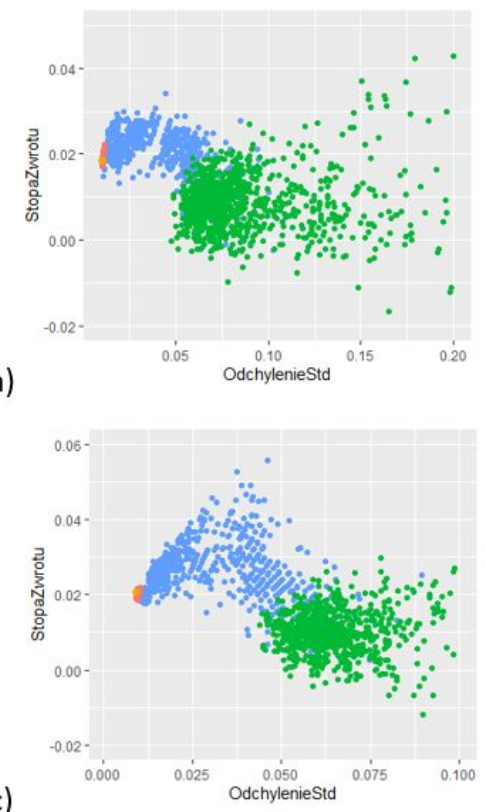

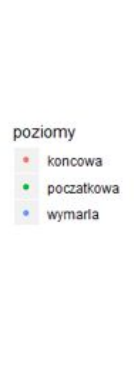

b)
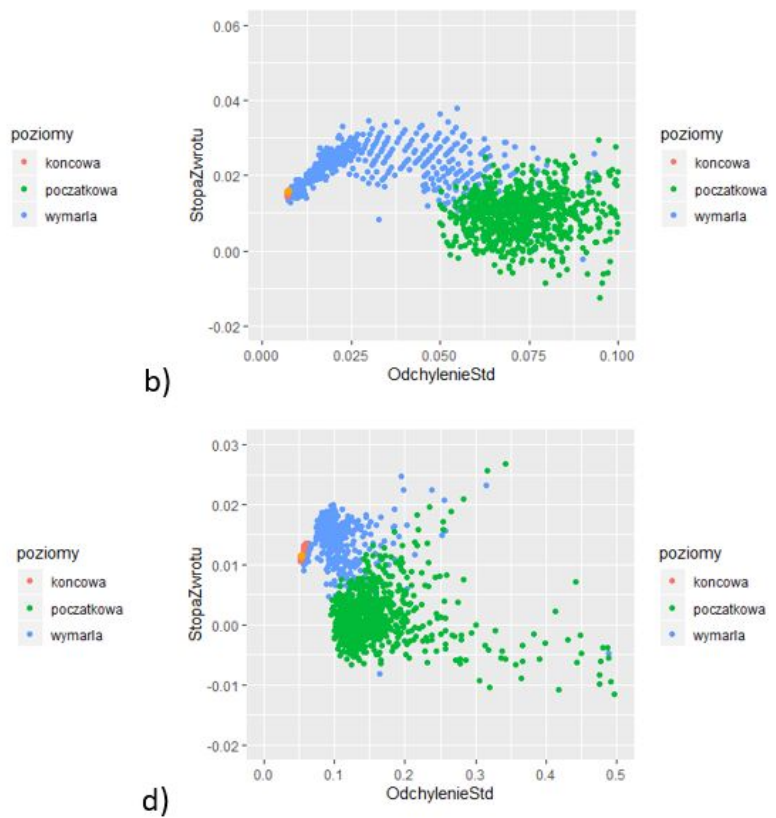

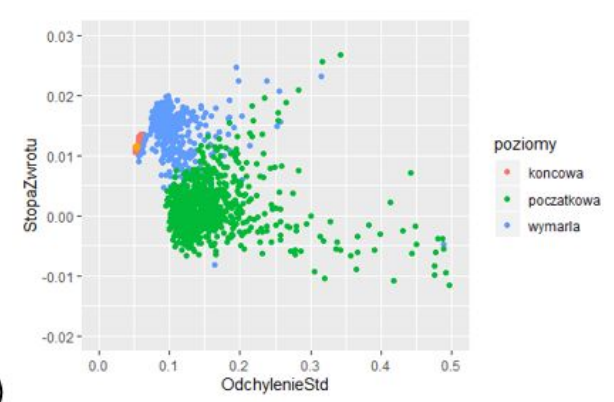

Fig. 10. Transition of the population of portfolios from initial, randomized portfolios (green points), through the extinct population (blue points) to the best portfolios (red points) in a genetic algorithm using the objective function with semi-variance and the first type of crossover operator and mutation; the orange point marks the optimal portfolio; a) portfolios from the period from 1/31/2015 to 6/30/2016;

b) portfolios from the third period, i.e. from 1/31/2016 to 6/30/2017; c) portfolios from the eighth period, i.e. from 7/31/2018 to 12/31/2019 d) changes for the entire time window, i.e. from 1/31/2015 to 31/03/2015; Source: own study 
Results for evolution changes for the objective function with semi-variance and the second type of crossover operator and mutation is shown in Figure 11. Again the evolution process has been presented in colors, i.e. moving from portfolios from the initial population (green), through the extinct population (blue) all the way to the final population (hardly visible in red). The estimated optimal portfolio is marked with an orange point.

a)
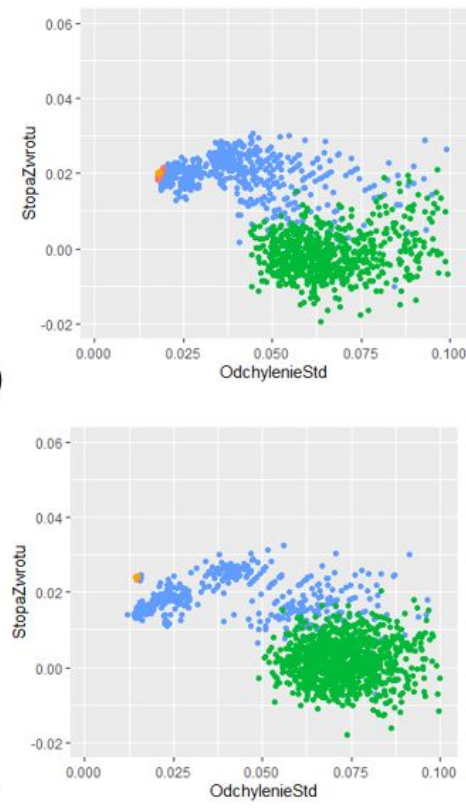

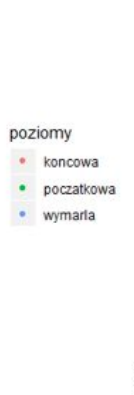

b)
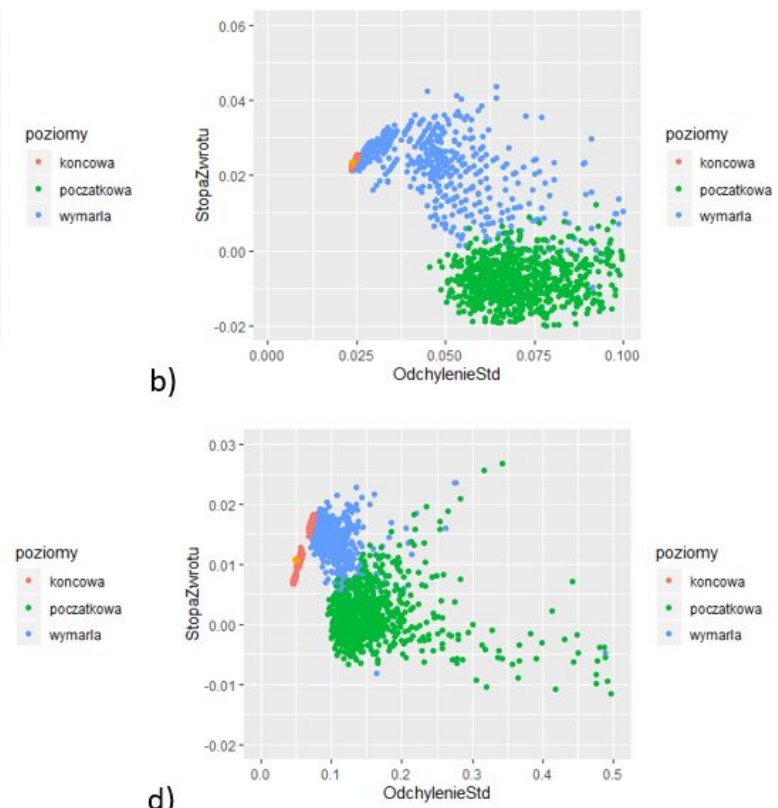

d)

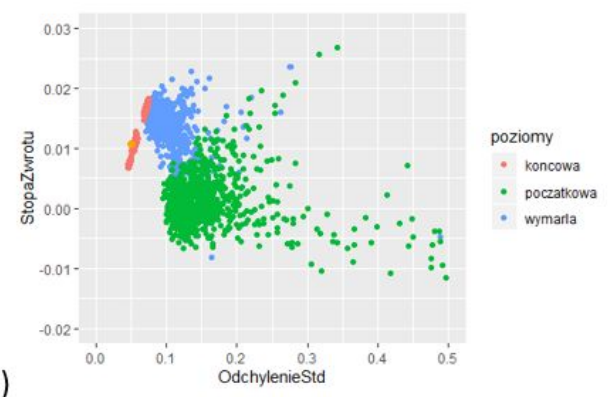

Fig. 11. Transition of the population of portfolios from initial, randomized portfolios (green points), through the extinct population (blue points) to the best portfolios (red points) in a genetic algorithm using the objective function with semi-variance and the second type of crossover operator and mutation; the orange point marks the optimal portfolio; a) portfolios from the period from 1/31/2015 to 6/30/2016;

b) portfolios from the third period, i.e. from 1/31/2016 to 6/30/2017; c) portfolios from the eighth period, i.e. from 7/31/2018 to 12/31/2019 d) changes for the entire time window, i.e. from 1/31/2015 to 31/03/2015; Source: own study

\section{CONCLUSIONS}

The presented piece of research is another building up block in optimizing the issue of determining the optimal portfolio in Markowitz's theory. In the era of technology advances, fast computers, fast matrix operations in scripting languages such as R-project or python, building an application that allows you to yield the set of an optimal stock portfolio relatively quickly seems to be relatively simple, straightforward and effective. The waiting times for results in the conducted experiments ranged from about 3 minutes to about 24 minutes, which is a time satisfactory suitable for the 
investor. To this time, you should also further add the time to download data from the website. These types of applications are an interesting tool supporting decision making in stock investing based on historical data.

A summary of the best results from the portfolios presented above are collected in Table 9. To sum up, the results of the best portfolios applying both variance and semivariance presented in Table 9 show the effectiveness of using evolutionary algorithms. The best randomized portfolio with the use of the variance obtained a result over 24 times lower than after applying the genetic algorithm in the same time window. The optimal evolutionary portfolio with the participation of the semi-variance and with the highest quotient of rate of return obtained a result 22 times higher than a randomized portfolio created on the basis of data from the same period. Particularly noteworthy is the portfolio created in the time window $1 / 31 / 2015-6 / 30 / 2016$ using variance, which increased its ratio of rate of return and variance over 110 times.

Table 9. Summary of randomized and evolutionary portfolio results that achieved the highest ratio of rate of return and variance/semi-variance

\begin{tabular}{|c|c|c|c|c|c|}
\hline & \multirow[t]{2}{*}{ Time window } & $\begin{array}{l}\text { No of } \\
\text { shares }\end{array}$ & $\begin{array}{l}\text { Rate of } \\
\text { return }\end{array}$ & $\begin{array}{c}\text { Standard } \\
\text { deviation } \\
\text { or semi-deviation }\end{array}$ & $\begin{array}{c}\text { Quotient of } \\
\text { rate of return } \\
\text { and variance or } \\
\text { semi-variance }\end{array}$ \\
\hline & & \multicolumn{4}{|c|}{ Randomly obtained stock portfolio } \\
\hline \multirow{2}{*}{$\begin{array}{l}\text { Application of } \\
\text { variance }\end{array}$} & $31^{\text {st }} \operatorname{Jan} 2016-30^{\text {th }}$ Jun 2017 & $\mathrm{n}=48$ & 0.02480 & 0.02801 & 31.61086 \\
\hline & $31^{\text {st }}$ Jan $2015-30^{\text {th }}$ Jun 2016 & $\mathrm{n}=45$ & 0.01725 & 0.02898 & 20.53976 \\
\hline \multirow{3}{*}{$\begin{array}{l}\text { Application of } \\
\text { semi-variance }\end{array}$} & $31^{\text {st }} \operatorname{Jan} 2016-30^{\text {th }} \operatorname{Jan} 2017$ & $\mathrm{n}=40$ & 0.02480 & 0.02801 & 31.61086 \\
\hline & $31^{\text {st }}$ Jan $2015-30^{\text {th }}$ Jun 2016 & $\mathrm{n}=45$ & 0.01725 & 0.02898 & 20.53976 \\
\hline & Time window & \multicolumn{4}{|c|}{ Genetic received stock portfolio } \\
\hline \multirow{2}{*}{$\begin{array}{l}\text { Application of } \\
\text { variance }\end{array}$} & $31^{\text {st }}$ Jan $2016-30^{\text {th }}$ Jun 2017 & $\mathrm{n}=51$ & 0.01450 & 0.00435 & 767.50806 \\
\hline & $31^{\text {st }}$ Jan $2015-30^{\text {th }}$ Jun 2016 & $\mathrm{n}=39$ & 0.01690 & 0.00272 & 2276.47310 \\
\hline \multirow{2}{*}{$\begin{array}{l}\text { Application of } \\
\text { semi-variance }\end{array}$} & $31^{\text {st }} \operatorname{Jan} 2016-30^{\text {th }}$ Jan 2017 & $\mathrm{n}=54$ & 0.01272 & 0.00876 & 165.91840 \\
\hline & $31^{\text {st }}$ Jan $2015-30^{\text {th }}$ Jun 2016 & $\mathrm{n}=37$ & 0.01818 & 0.00621 & 470.94261 \\
\hline
\end{tabular}

The proposed algorithm has shown that the determination of optimal portfolios is within the investor's reach, with a relatively small amount of time (in real applications you should also add time to download data, pre-process it and pre-calculate the rates of return and variances). Of course, published algorithms can be developed until a meaningful tool for investors is obtained.

As a matter of fact, it is considered a tool based on historic data which can exclusively support investors when making decisions. Although, we should filter the results through future values and additional data, which undoubtedly may have a staggering impact on future outcomes for the listings.

It is certainly justified to continue research on the modifications of portfolio theories. 


\section{REFERENCES}

Czekała, M., 1997. Rynek kapitałowy. Analiza fundamentalna i techniczna. Wydawnictwo Akademii Ekonomicznej im. Oskara Langego we Wrocławiu, Wrocław.

Dorostkar-Ahmadi, N., Shafiei Nikabadi, M., 2018. A nonlinear multi objective model for the product portfolio optimization: An integer programming. International Journal of Nonlinear Analysis and Applications, 9(2), 231-239, doi: https://doi.org/10.22075/ ijnaa.2018.13447.1695.

Fabozzi, F.J., Gupta, F., Markowitz, H.M., 2002. The Legacy of Modern Portfolio Theory. The Journal of Investing Fall, 11(3), pp. 7-22.

Fama, E.F., 1970. Efficient Capital Markets: A Review of Theory and Empirical Work. The Journal of Finance, 25(2), pp. 383-417.

Figielska, E., 2006. Algorytmy ewolucyjne i ich zastosowania. Zeszyty Naukowe Warszawskiej Wyższej Szkoty Informatyki, 1, pp. 81-92.

Goldberg, D.E., 1989. Genetic Algorithms in Search. Optimization and Machine Learning. Addison-Wesley Longman Publishing Co. Inc., Boston., MA.

Goldberg, D.E., Sastry, K., 2001. A practical schema theorem for genetic algorithm design and tuning. In: Proceedings of the Genetic and Evolutionary Computation Conference, pp. $328-335$

Graham, B., 2006. Inteligentny inwestor. Studio EMKA, Warszawa.

Gwiazda, T., 1998. Algorytmy genetyczne - zastosowania w finansach. Wydawnictwo Wyższej Szkoły Przedsiębiorczości i Zarządzania im. L. Koźmińskiego, Warszawa.

Haugen R.A., Modern Investment Theory (fifth edition), Prentice Hall, Pearson 2000

Jajuga, K., Jajuga, T., 2006. Inwestycje. Instrumenty finansowe, aktywa niefinansowe, ryzyko finansowe, inżynieria finansowa. PWN, Warszawa.

Janikow, C.Z., Machalewicz, Z., 1991. An Experimental Comparison of Binary and Floating Point Representation in Genetic Algorithms. Computer Science. ICGA., url: http://umsl.edu/divisions/artscience/math_cs/about/People/Faculty/ CezaryJanikow/folder\%20two/Experimental.pdf [access date: 15.02.2020].

Jasiński, G., 2008. Ewolucyjna optymalizacja w nowoczesnej teorii portfelowej. Scientific Bulletin of Chetm. Section of Mathematics and Computer Science, 1, pp. 113-122.

Jiao, J., Zhang, Y., Wang, Y., 2007. Heuristic genetic algorithm for product portfolio planning. Computers \& Operations Research, 34, pp. 1777-1799, doi: https://doi.org/10.1016/ j.cor.2005.05.033.

Kachniewski,, M., 2008. Rynek kapitałowy i giełda papierów wartościowych. Fundacja Edukacji i Rynku Kapitałowego, Warszawa.

Krzywda, M., 2010. GPW I - Giełda Papierów Wartościowych w praktyce. Złote Myśli, Gliwice, https://www.cdmpekao.com.pl/edukacja/wszystko-o-analizach-gieldowych.

Markowitz, H.M., 1952. Portfolio Selection, The Journal of Finance, 7(1), s. 77-91, doi: https://doi.org/10.2307/2975974, JSTOR: 2975974.

Markowitz, H.M., 1959. Portfolio selection: Efficient Diversification of Investments. Yale University Press, New Haven.

Michalewicz, Z., 2003. Algorytm genetyczny + struktury danych = programy ewolucyjne. Wydawnictwo Naukowo-Techniczne, Warszawa.

Morajda, J., 1999. Metody sztucznej inteligencji w zarzadzaniu portfelem inwestycyjnym. Akademia Ekonomiczna, Kraków [praca doktorska]. 
Motyczyńska, J., 2019. Analiza ryzyka w portfelach akcji wybranych spółek na Warszawskiej Giełdzie Papierów Wartościowych. AGH, Kraków [praca licencjacka].

Orito, Y., Yamazaki, G., 2001. Index fund portfolio selection by using GA. Proceedings of the Fourth International Conference on Computational Intelligence and Multimedia Applications (ICCIMA), pp. 118-122, doi: https://doi.org/10.1109/ICCIMA.2001.970454.

Ostrowska, E., 2011. Portfel inwestycyjny klasyczny i alternatywny. C.H. Beck, Warszawa.

Sawik, B. 2009. A Reference Point Approach to Bi-Objective Dynamic Portfolio Optimization. Decision Making in Manufacturing and Services, 3(2), pp. 73-85, doi: https://doi.org/ 10.7494/dmms.2009.3.2.73.

Sawik, B., 2010. A Bi-Objective Portfolio Optimization with Conditional Value-at-Risk. Decision Making in Manufacturing and Services, 4(2), pp. 47-69, doi: https://doi.org/ 10.7494/dmms.2010.4.2.47.

Sawik, B., 2012. Downside Risk Approach for Multi-Objective Portfolio Optimization. In: Klatte, D., Lüthi, H.J., Schmedders, K. (eds.), Operations Research Proceedings 2011. (GOR (Gesellschaft für Operations Research e.V.)). Springer, Berlin, Heidelberg, https: //doi.org/10.1007/978-3-642-29210-1_31.

Sharpe, W.F., 1992. Asset Allocation: Management Style and Performance Measurement. The Journal of Portfolio Management, 18, pp. 7-19.

Talebi, A., Molaei, M., Sheikh, M. 2010. Performance Investigation and Comparison of Two Evolutionary Algorithms in Portfolio Optimization: Genetic and Particle Swarm Optimization. In: Proceedings - 2010 2nd IEEE International Conference on Information and Financial Engineering, ICIFE 2010, pp. 430-437, doi: https://doi.org.10.1109/ ICIFE.2010.5609394.

Tarczyński, W., 1996. Analiza portfelowa na giełdzie papierów wartościowych. PTE, Szczecin.

Tarczyński, W., 2001. Rynki kapitałowe. Metody ilościowe. Placet, Warszawa,.

Tarczyński, W., 2002. Fundamentalny portfel papierów wartościowych. PWE, Warszawa.

Tarczyński, W., 2014. Ocena różnych wariantów fundamentalnego portfela papierów wartościowych. Prace Naukowe Uniwersytetu Ekonomicznego we Wrocławiu, 371, pp. 298-309. In: Jajuga, K., Ronka-Chmielowiec W. (Eds.), Inwestycje finansowe i ubezpieczenia tendencje światowe a rynek polski, Wrocław.

Tarczyński, W., Łuniewska, M., 2004. Dywersyfikacja ryzyka na polskim rynku kapitałowym. Placet, Warszawa.

R Core Team, 2019. R: A language and environment for statistical computing. R Foundation for Statistical Computing. Vienna. Austria, url: https://www.R-project.org/.

RStudio Team, 2019. RStudio: Integrated Development for R. RStudio, Inc., Boston, MA, url: http://www.rstudio.com/. 